Chicago-Kent College of Law

Scholarly Commons @ IIT Chicago-Kent College of Law

January 1986

\title{
Extraterritorial Discovery and the Conflict of Procedural Systems: Germany and the United States
}

David J. Gerber

IIT Chicago-Kent College of Law, dgerber@kentlaw.iit.edu

Follow this and additional works at: https://scholarship.kentlaw.iit.edu/fac_schol

Part of the Comparative and Foreign Law Commons, and the Evidence Commons

\section{Recommended Citation}

David J. Gerber, Extraterritorial Discovery and the Conflict of Procedural Systems: Germany and the United States, 34 Am. J. Comp. L. 745 (1986).

Available at: https://scholarship.kentlaw.iit.edu/fac_schol/229

This Article is brought to you for free and open access by the Faculty Scholarship at Scholarly Commons @ IIT Chicago-Kent College of Law. It has been accepted for inclusion in All Faculty Scholarship by an authorized administrator of Scholarly Commons @ IIT Chicago-Kent College of Law. For more information, please contact jwenger@kentlaw.iit.edu, ebarney@kentlaw.iit.edu. 
DAVID J. GERBER

\section{Extraterritorial Discovery and the Conflict of Procedural Systems: Germany and the United States}

When the explosion of an automobile in Kansas causes serious injury and there is a possibility that it was caused by a defective part made outside the United States, limitations on the plaintiff's discovery rights due to the foreign location of witnesses or documents are likely to be seen in the United States as violations of basic concepts of procedural justice. Conversely, to the foreign manufacturer defendant, being coerced to submit to unlimited American discovery procedures because one of the parts manufactured by him might have been defective may also violate basic concepts of procedural justice. In such cases, therefore, the application of United States discovery rules to evidence located outside the United States often involves fundamental differences in legal process and a clash between concepts of procedural justice. The result is an intense and escalating international controversy. ${ }^{1}$

Operating on the basis of domestic concepts of justice, American courts consider themselves justified in applying American discovery rules extraterritorially (i.e., to require conduct outside the United States). ${ }^{2}$ In response, foreign governments seek to protect their own interests and concepts of justice by attempting to prevent or limit such applications. The measures taken have included diplomatic pressure on the United States government, ${ }^{3}$ participation in U.S. liti-

DAvid J. GERBER is Associate Professor of Law, IIT/Chicago-Kent College of Law.

1. Various aspects of the controversy are treated in Symposium, "Compelling Discovery in Transnational Litigation," 16 N.Y.U. J. Int'l L. \& Pol. 957-1167 (1984). See also, e.g., Shemanski, "Obtaining Evidence in the Federal Republic of Germany: The Impact of American Judicial Cooperation," 17 Int'l Lawyer 465, 466 (1983); Note, "The Hague Convention on the Taking of Evidence Abroad in Civil or Commercial Matters: The Exclusive and Mandatory Procedures for Discovery Abroad," $132 U$. Pa. L. Rev. 1461, 1464 (1984); von Huelsen, "Gebrauch and Missbrauch US-amerikanischer 'pre-trial discovery' and die internationale Rechtshilfe," 28 Recht der Internationalen Wirtschaft 225 (1982); and Focsaneau, "L'Instruction Extraterritoriale des Litiges Economique et la Defense de la Souveranete des Etats," 1981 Annuaire Français de Droit International 628.

2. See, e.g., In re Anschuetz \& Co., 754 F.2d 602 (5th Cir. 1985).

3. See, e.g., Note, Embassy of Fed. Rep. of Germany to U.S. Dept. of State (20 Aug. 1982), printed in Brief for the U.S. as Amicus Curiae, at Appendix, Volkswagenwerk A.G. v. Falzon et al., 461 U.S. 1303 (1983). 
gation, ${ }^{4}$ and, in some cases, the passage of so-called "blocking legislation" designed to impede American discovery efforts. ${ }^{5}$

This conflict has led to substantial confusion on the part of lawyers, litigants and judges, and this uncertainty substantially increases the costs and risks of transnational litigation. These increased costs of doing business in the United States tend to lead, in turn, to higher costs to American consumers and a reduced flow of certain goods to the United States. In addition, the conflict creates significant costs for the U.S. government as well as for foreign governments, and it has a negative impact on the foreign relations of the United States.

The conflict over extraterritorial discovery results from differences between the U.S. procedural system and the procedural systems of the other countries involved in the controversy. Such differences provide the main reasons why foreign countries resist U.S. discovery, and they also provide the conceptual framework within which disputes concerning extraterritorial discovery are approached. Yet the role of these systemic differences seems to be little understood, particularly in the United States. American lawyers and judges are generally unaware of the differences between procedural systems which lead foreign governments to resist the application of American discovery rules to conduct within their territories, and foreign lawyers and judges often fail to understand American discovery procedures and the functions they perform within the American procedural system.

The controversy over extraterritorial discovery is not entirely new, ${ }^{6}$ but its importance and severity have dramatically increased in recent years. A variety of factors have led to this development. First, U.S. discovery rules have been expanded to permit more extensive pre-trial discovery outside the U.S. ${ }^{7}$ Second, until 1983, the availability of discovery under U.S. law had been generally increas-

4. See, e.g., Graco Inc. v. Kremlin, Inc., 101 F.R.D. 503 (N.D. Ill. 1984).

5. For general discussions of blocking legislation, see Cira, "The Challenge of Foreign Laws to Block American Antitrust Actions," 18 Stan. J. Int'l L. 247 (1982) and Gerber, "Beyond Balancing: International Law Restraints on the Reach of National Laws," 10 Yale J. Int'l L. 185, 219-220 (1985).

6. See generally, e.g., Jones, "International Judicial Assistance: Procedural Chaos and a Program for Reform," 62 Yale L.J. 515 (1953); Volkommer, "Disharmonien and Spannungen im internationalen Rechtshilfeverkehr zwischen den U.S.A. und Deutschland," 80 Zeitschrift für Zivilprozess 248 (1967); and Onkelinx, "Conflict of International Jurisdiction: Ordering the Production of Documents in Violation of the Law of the Situs," $64 \mathrm{Nw}$. U.L. Rev. 487 (1969).

7. The most important change occurred in 1963, when Rule 28(b)(1) of the Federal Rules of Civil Procedure (hereinafter "Fed. R. Civ. P." or "the Federal Rules") was amended "to facilitate depositions in foreign countries by enlarging the class of persons before whom the depositions may be taken on notice." Fed. R. Civ. P. 28(b) 1963 advisory committee note. For a discussion of these developments, see 4 Moore's Federal Practice $\S \S 28.01$ and 28.03-28.08. 
ing for several decades. ${ }^{8}$ Third, concepts of personal jurisdiction have been significantly expanded during recent decades, making it easier for U.S. courts to acquire jurisdiction over foreign defendants. ${ }^{9}$ Fourth, the substantive law of products liability has been broadened, with a resulting increase in both the likelihood and the size of damage awards for defective products. ${ }^{10} \mathrm{Fifth}$, and paradoxically, the preparation and operation of an international treaty on evidence-taking, the Hague Evidence Convention, ${ }^{11}$ has led to misunderstandings and unfulfilled expectations on both sides. ${ }^{12}$ And, finally, changes in trade and investment patterns have increased the probability of U.S. product liability suits against foreign manufacturers by making it increasingly likely that consumer durable items sold in the U.S. will have components manufactured abroad. ${ }^{13}$

This article, therefore, analyzes the differences between legal systems that play a significant role in the controversy and then analyzes the controversy itself in light of these systemic differences. The objectives are, first, to identify and explain the systemic differences which lead to resistance to the use of U.S. discovery methods and impede development of an effective legal framework for transnational evidence-taking and, second, to identify potential avenues for improving the current situation.

A central fact about the controversy over extraterritorial discov-

8. The relevancy requirement was eviscerated by the Supreme Court in 1948 in Hickman v. Taylor, 329 U.S. 495 (1947), where "fishing expeditions" were specifically approved. Another key development was the 1970 change in the Federal Rules which deleted the requirement of a showing of "good cause" to enforce the production of documents.

9. See, e.g., Lilly, "Jurisdiction over Domestic and Alien Defendants," 69 Va. L. Rev. 85 (1983). See also Juenger, "Judicial Jurisdiction in the United States and in the European Economic Communities: A Comparison," 82 Mich. L. Rev. 1195 (1984) for a comparison which suggests that the area of personal jurisdiction is contracting in some areas while expanding in cases involving products liability claims.

10. See, e.g., Wheeler, "A Brief History of the Development of Modern Products Liability Law," in Product Design Liability 13 (Wheeler ed. 1981). See also Gilmore, "Products Liability: A Commentary," 38 U. Chi. L. Rev. 103 (1970), and Posner, "Strict Liability: A Comment," 2 J. Leg. Stud. 205 (1973).

11. Hague Convention on the Taking of Evidence Abroad in Civil or Commercial Matters, opened for signature 18 March 1970, 23 U.S.T. 2555, T.I.A.S. 7444, 847 U.N.T.S. 231.

12. See infra, pt. III. Attention was focused on problems in this area by the very well-publicized "Westinghouse Uranium Litigation." See In re Westinghouse Elec. Corp. Uranium Contracts Litigation, 563 F.2d 992 (10th Cir. 1977) and In re Uranium Antitrust Litigation, 480 F. Supp. 1138 (N.D. Ill. 1979). For discussion, see Augustine, "Obtaining International Judicial Judicial Assistance Under the Federal Rules and the Hague Convention on the Taking of Evidence Abroad in Civil or Commercial Matters: An Exposition of the Procedures and a Practical Example: In re Westinghouse Uranium Contracts Litigation," $10 \mathrm{Ga}$. J. Int'l \& Comp. L. 101 (1980).

13. See, e.g., "The Latest Foreign Beachhead," Forbes, 13 Oct. 1980, at 42, reporting that $10 \%$ to $15 \%$ of all car parts in domestic cars are from foreign manufacturers. 
ery is that it finds the United States in conflict with "the rest of the world". Nevertheless, in order to keep the analysis here within manageable bounds, this article will focus on the extraterritorial discovery controversy in the context of legal relations between the United States and the Federal Republic of Germany. Germany is a civil law country, and, therefore, elements of the German legal system relating to this controversy are generally similar to those of other countries of the civil law tradition. ${ }^{14}$ Moreover, German firms and the German government have been frequently and intensely involved in the controversy, and, as a result, there is a substantial amount of legal material on that conflict.

This article will deal only with the application of U.S. discovery rules in the context of civil litigation. The problems that arise when government agencies seek extraterritorial discovery-e.g., in criminal or administrative proceedings-involve a series of distinct issues which will not be analyzed here. ${ }^{15}$

\section{Differences in Procedural Systems}

The controversy over extraterritorial discovery is rooted in differences between the respective procedural systems of Germany and the United States. The differences in civil litigation which are particularly relevant to the controversy over extraterritorial discovery can be grouped into four categories: (1) the structure of the litigation process itself; (2) the respective roles assigned to the participants in that process; (3) the treatment of information within the process; and (4) the scope of evidentiary obligations. ${ }^{16}$

\section{A. The Structure of the Litigation Process}

In two areas, in particular, differences between the American and German litigation processes have contributed to the controversy over extraterritorial discovery. ${ }^{17}$ The first relates to whether the lit-

14. See generally International Cooperation in Litigation: Europe (Smit ed. 1965); Nagel, Die Grundzüege des Beweisrechts im europäischen Zivilprozess (1967); Schlosser, Der Justizkonflikt zwischen den USA and Europa 17-22 (1985); and Millar, "The Mechanism of Fact-Discovery: A Study in Comparative Civil Procedure IV," $32 \mathrm{Ml}$. L. Rev. 424 (1937). For discussion of modern trends in this area, see Capelletti, "Social and Political Aspects of Civil Procedure," 69 Mich. L. Rev. 847 (1971).

15. See, e.g., U.S. v. Bank of Nova Scotia, 740 F.2d 817 (11th Cir. 1982), cert. denied, 105 S. Ct. 778 (1985).

16. For discussion of the problem of comparing the German and American systems, see Kaplan, "Civil Procedure: Reflections on the Comparison of Systems," 9 Buffalo L. Rev. 409 (1960) and Grossfeld, "Probleme der Rechtsvergleichung im Verhaeltnis Vereingte Staaten von Amerika-Deutschland," 39 RabelsZ. 5 (1975).

17. The term "litigation process" is here used to denote the state-regulated process whereby a private conflict is presented to, and resolved by, a court of law; it does not include actions which are not regulated by the state - e.g., private investi- 
igation process at first instance is unified or divided into a trial and pre-trial phase, and the second involves the relationship between the treatment of facts and the treatment of legal issues in the two systems.

The litigation process in the United States consists of two separate but interdependent components-the pre-trial stage and the trial itself. This division of the litigation process is often misunderstood outside the United States, and an important element of the controversy over international discovery relates to the issue of whether U.S. pre-trial discovery is part of the litigation process for purposes of international judicial cooperation. ${ }^{18}$

In the Common Law tradition the central component of the litigation process is the trial. Because of the presence of a lay jury within the system, the trial is necessarily continuous, which means that there is usually little opportunity to discover new facts during the course of the procedure itself. Consequently, each party must prepare his case before the trial. ${ }^{19}$ As unlimited access to facts became increasingly valued in the American legal system, ${ }^{20}$ and as evidence, especially documentary evidence, became increasingly available, the litigation process was expanded to include the search for information to be used at the trial, and state power is now available to enforce compliance with the attorneys' requests for information. ${ }^{21}$

The creation of a pre-trial procedure was intended, among other things, to reduce the length of trials and increase their effectiveness by requiring fact issues to be clarified prior to the proceeding it-

gation of the facts of a controversy. This point must be emphasized, because there is a tendency in the United States to view discovery as "private" activity, even though it is authorized and regulated by the states.

18. See infra, text accompanying n. 180-186.

19. In the civil procedure of the United Kingdom, preparation of the case must also occur before trial, but discovery is allowed only where the party seeking discovery specifies the material to be examined and demonstrates its relevance. Thus the U.K. position on this point is essentially similar to that of the civil law countries, and the U.K. has actively sided with the civil law countries in the extraterritorial discovery controversy. For a discussion of discovery in England and a comparison of the U.S. and British discovery systems, see Levine, Discovery: A Comparison Between English and American Civil Discovery Law (1982). See also Cappelletti \& Garth, "A Comparative Conclusion," in Civil Procedure, XVI Int'l Encyc. Comp. L. 249, 252-53, and Myrick \& Love, "Obtaining Evidence Abroad in United States Litigation," 35 Sw. L.J. 858, 597-609 (1981).

20. For a discussion of this development, see Purcell, The Crisis of Democratic Theory 74-94, 159-179 (1973).

21. The major change occurred in 1938 , when discovery in its modern form was introduced into the Federal Rules. For accounts of the changes, see, e.g., Holtzhoff, "Instruments of Discovery under Federal Rules of Civil Procedure," 41 Mich. L. Rev. 105 (1942) and Pike \& Willis, "The New Federal Deposition-Discovery Procedure (pts. 1 \& 2)," 38 Colum. L. Rev. 1179, 1436 (1936). See also Glaser, Pre-trial Discovery and the Adversary System 18-37 (1968). 
self. ${ }^{22}$ It was a direct response to the constraints imposed by a juryoriented trial procedure. From the perspective of U.S. law, therefore, pretrial discovery is an integral and necessary part of the litigation process.

In Germany, in contrast, there is no "trial" in the American sense of the term. ${ }^{23}$ Hence there is no need for a "pre-trial" phase of litigation. Because there is no jury, the litigation process can develop in relatively informal stages. The process may consist of several "hearings", and evidence may be received on more than one occasion. ${ }^{24}$ At each stage of the proceeding, the judge is present and "in control", and only those procedures in which the judge participates are part of the litigation process. Thus, the litigation process is effectively coterminous with the judicial process.

From the perspective of German law, therefore, U.S. pre-trial discovery is often misunderstood to represent preparation for the litigation process and therefore not actually to be part of that process. This misapprehension is strengthened by the fact that discovery procedures are labelled "pre-trial," which is often understood to mean "pre-litigation process". 25

Where discovery procedures are considered to be merely preparatory for the litigation process, they are presumed not to be entitled to be treated as part of that process in the international context. ${ }^{26}$ Therefore, it is argued, foreign governments may not be expected to cooperate with the U.S. by providing international judicial assistance in relation to pre-trial procedures, for such assistance is intended to relate only to the litigation process itself.

A second structural factor related to the extraterritorial discovery controversy concerns the manner in which "law" is procedurally

22. The stated purposes of the new procedures are discussed in Brazil, "The Adversary Character of Civil Discovery: A Critique and Proposals for Change," 31 Vand. L. Rev. 1295, 1298-1303 (1978).

23. Recent reforms in German civil procedure have, however, attempted to "focus" court proceedings and reduce the number of separate litigation episodes. For a discussion of these changes, see Fisch, "Recent Developments in West German Civil Procedure," 6 Hastings Int'l and Comp. L. Rev. 221, 226 (1983) and Gottwald, "Simplified Civil Procedure in West Germany," $31 \mathrm{Am}$. J. Comp. L. 687 (1983).

24. For a description of this process, see Kaplan, von Mehren \& Schaefer, "Phases of German Civil Procedure I," 71 Harv. L. Rev. 1193, 1211 (1958). This article remains the most complete and authoritative description of German Civil procedure in English. A major part of the article was updated as of 1977 in von Mehren \& Gordley, The Civil Law System 151 (2d ed. 1977).

25. See generally "Report of the Work of the Special Commission on the Operation of the Convention of 18 March 1970 on the Taking of Evidence Abroad in Civil or Commercial Matters," 17 Int'l Leg. Mat. 1425 (1978) [hereinafter cited as "1978 Commission Report"]. For further discussion, see Oxman, "The Choice Between Direct Discovery and Other Means of Obtaining Evidence Abroad: The Impact of the Hague Evidence Convention," 37 U. Miami L. Rev. 733, 772 n. 110 (1983).

26. See infra, text accompanying n. 180-86. 
related to "facts". In the American litigation process, the process of establishing facts is distinct from the process of determining and applying law. The former includes both pre-trial discovery and the trial itself. It is highly regulated and highly visible, and it often involves the expenditure of extensive resources by parties, witnesses and even by the state itself. It is clearly the central part of the litigation process.

In contrast, the process of determining law plays a more peripheral role, being subject to minimal procedural requirements and generally not highly visible. ${ }^{27}$ The judge is solely responsible for determining the applicable law and generally has great discretion with regard to the procedure for performing that function. Legal issues may be presented by the attorneys orally or in writing, with few limits on the judge's discretion as to the form in which such arguments are to be presented and the extent to which they will be considered.

This procedural separation of the law-determination and factdetermination functions has resulted from the presence of the jury. ${ }^{28}$ Since a lay jury is responsible for determining issues of fact, and since it has been thought that its members could only be confused and misled by discussion of legal issues, ${ }^{29}$ legal issues are not presented to the jury and are relegated to a separate procedure.

In Germany, legal and factual issues are presented and evaluated as part of the same process. From the inception of the litigation process to its termination, issues of fact and issues of law are continually and necessarily intertwined, and the unity of the litigation process derives from the fact that the judge is responsible for the determination of both facts and law as well as for the application of law to facts. ${ }^{30}$

From the German perspective, the fact-determination procedure cannot be divorced from the law determination and application procedures without changing the nature of the litigation process. In particular, where fact-determination is an essentially separate procedure, there is no means of supervising the gathering of facts and assuring that only those facts are gathered which are directly relevant to the case. As a result, the American system of fact-determination appears alien-and potentially offensive-to German principles of procedure.

27. The law-determination process is obviously not peripheral in the sense of being unimportant or even less important than the fact-determination process. It is peripheral only in the sense of not being the central focus of the litigation process.

28. See generally James \& Hazard, Civil Procedure 302-313 (3rd ed. 1985).

29. See generally Friedenthal, Kane \& Miller, Civil Procedure 470-74 (1985).

30. See Kaplan, von Mehren \& Schaefer, supra n. 24 at 1225-1228. 


\section{B. Role Assignments: Who Does What?}

Related to these differences in the structure of the respective litigation processes are differences relating to the respective roles of the participants in the litigation process-the issue of who does what. The two procedural models define the roles of judge and attorney in the litigation process very differently, and a key participant in the American process-the jury-is not even present in the German litigation process.

In order to compare the German and U.S. processes more effectively, one can analyze the litigation process into several distinct components: fact investigation, fact presentation, fact determination and law presentation, law determination, and law application.

In the U.S., attorneys have virtually sole responsibility for fact investigation and fact presentation, and thus their roles dominate both the pre-trial and trial proceedings. They are authorized to depose witnesses, examine documents and demand answers to written interrogatories, and the state enforces compliance with their demands for information. Thus the state clothes attorneys with extensive authority to coerce private conduct merely because they represent parties in pending litigation. Such fact investigation authority granted to attorneys in the U.S. appears to exceed that granted by any other state.

Moreover, the state only minimally supervises the exercise of this authority, even though such proceedings often involve extensive financial and other burdens as well as interference with personal freedom. The judge is not present during discovery proceedings. He may issue protective orders restricting discovery, but the grounds for issuing such orders are limited and poorly defined, and the party seeking such a protective order bears the burden of persuading the judge that it should be issued. ${ }^{31}$ Consequently, the attorneys have extensive authority to determine who must submit what to discovery procedures as well as substantial discretion with respect to the conduct of the proceedings.

Attorneys generally have similarly broad control of the factpresentation process. ${ }^{32}$ Each attorney actually presents his client's factual case; he has what may be called "configurative authority" with respect to the presentation of information to the trier of fact. This means that he generally determines the order in which his wit-

31. See generally, U.S. v Int'l Business Machines, 81 F.R.D. 628 (D.C.N.Y. 1979), which suggests that the very heavy burden of proof on the proponent is the reason why protective orders are issued so infrequently. For commercial information the burden is especially heavy. See, e.g., Citicorp. v. Interbank Card Assn., 478 F. Supp. 756 (D.C.N.Y. 1979).

32. For a general description of this aspect of the trial process, see Friedenthal, Kane \& Miller, supra n. 29 at $453-458$ (1985). 
nesses will be called and the timing and circumstances for the presentation of his documentary evidence. ${ }^{33}$ Moreover, the attorneys generally control the form of testimony, because witnesses may only present information in response to specific questions of the attorneys.

The American judge's role during the trial is primarily that of a referee between opposing attorneys. ${ }^{34}$ Only rarely does he question witnesses or otherwise participate in the fact presentation process. The judge has virtually unlimited control over the law-determination procedure, but since the law-determination procedure is separated from the fact-determination procedure, the judge's central role in the former does not affect his limited role in the latter.

In the American system there is a third participant in the litigation process-the jury, ${ }^{35}$ whose role it is to decide issues of fact and apply the law to the facts in accordance with the judge's instructions. A trial may take place without a jury, but trial procedure is based on the assumption that there may be a jury, ${ }^{36}$ and the presence of the jury in the system thus significantly influences the characteristics of the system.

In sharp contrast, the German procedural system is dominated by the judge, who is solely responsible for performing the fact-determination, law-determination and law-application functions. ${ }^{37}$ Thus there is no procedural separation of these functions, as there is in the U.S. They are treated as essentially indivisible.

The fact that these functions are combined allows the judge to control all aspects of the litigation process. ${ }^{38} \mathrm{He}$ calls witnesses when and as he sees fit and thus determines the context and order of presentation of evidence. Moreover, it is primarily the judge who

33. In the federal courts the freedom of attorneys to control these matters has been limited in some cases by 1983 amendments to Fed. R. Civ. P. 16, which allow the judge, in consultation with the attorneys, to fashion a final pre-trial order establishing, inter alia, the order of presentation of evidence.

34. See generally, Fuller, "The Forms and Limits of Adjudication," 92 Harv. $L$. Rev. 353, 381-393 (1978). See also Friedenthal, Kane \& Miller, supra n. 29 at 457.

35. See generally Kalven \& Zeisel, The American Jury (1966).

36. There is an ongoing debate concerning the issue of whether the rules of evidence should be used by judges in bench trials. See generally, McCormick on Evidence 153-54 (3rd ed. 1984).

37. Although reference here is to the role of the judge, judging is often done in panels of three or more judges. See Fisch, supra n. 23 at 227-236.

38. During this century, judicial control over litigation proceedings has been seen as an antidote to procedural delay, and such control has been gradually increased in order to combat delay. The first major step in this direction was the reform of 1927. For details, see Engelmann, A History of Continental Civil Procedure 616-620 (Millar ed. 1927). For more recent steps, see Fisch, supra n. 23 at 225 and 254-260. According to Fisch, "Major reforms were adopted in 1909 and 1924, and lesser ones in 1933 and 1943, all designed principally to tighten judicial control over the course of the lawsuit and promote efficiency." Id. at 225. 
questions witnesses. ${ }^{39}$ Thus, the judge rather than the attorneys has configurative authority with respect to the presentation of evidence. The judge's power in this regard is augmented by the fact that he records testimony in summary narrative form, and in this form becomes part of the case file. There is generally no verbatim transcript of testimony. ${ }^{40}$

One of the judge's principal functions is to limit the scope of the proceedings. From the inception of the procedure the judge explores potential lines of argument in discussions with the attorneys and attempts to narrow the issues to those which are likely to be dispositive of the case. The result is that evidence-taking can be focused on those specific issues which have been identified as potentially dispositive. ${ }^{41}$

In most types of civil litigation, however, the judge's role is limited by a procedural principle known as the party-presentation principle (Verhandlungsmaxime). ${ }^{42}$ According to this principle, "the Court may take into consideration only those facts and assertions which the parties have presented to him. The judge may not on his own seek out new evidentiary material." 43

The judge also has an important "guidance" or "party-assistance" function. ${ }^{44}$ According to section 139 of the Code of Civil Pro-

39. According to ZPO section 397:

I. The parties are entitled to request that questions be posed to the witness which they consider useful in clarifying the factual situation or the circumstances (Verhaeltnisse) of the witness.

II. The presiding judge may allow parties and must, on request, allow their attorneys to pose questions directly to witnesses.

For a discussion of this section, see Baumbach \& Lauterbach, Zivilprozessordnung 1035 (43rd ed. 1985).

40. For a discussion of the procedures, see Rosenberg \& Schwab, Zivilprozessrecht 724-25 (13th ed. 1981). See also Baumbach \& Lauterbach, id. at 464-467.

41. See generally Bruns, Zivilprozessrecht 1040-50 (2d ed. 1979) and Langbein, "The German Advantage in Civil Procedure," 52 U. Chi. L. Rev. 823, 830-32 (1985). In Langbein's view, this "focusing" capacity of German civil procedure provides one of that system's main advantages over U.S. procedure.

42. The party-presentation principle is often contrasted with the so-called investigatory principle (Untersuchungsmaxime), according to which the judge is charged with actively investigating the facts of a case and is not limited to the material nominated by the parties.

Each principle is considered to have its own sphere of operation, and there is a sharp distinction between the two spheres. Thus the investigatory principle operates in certain kinds of litigation -e.g., much family law litigation, and where it operates the party-presentation principle, is a fortiori, no longer operative. For discussion of the investigatory principle and its relation to the party-presentation principle, see Engelmann, supra n. 38 at 11-18.

43. Nagel, supra n. 14 at 28. See also Engelmann, id. at 11.

44. For futher discussion, see Rosenberg \& Schwab, supra n. 40 at $437-443$ and Arens, Zivilprozessrecht 13-16 (3d ed. 1984). See also Kaplan, von Mehren \& Schaefer, supra n. 24 at 1224-1230; Fisch, supra n. 23 at 255-257; and Bernhardt, "Die Aufklaerung des Sachverhalts in Zivilprozess," in Festgabe für Leo Rosenberg - Beiträge zum Zivilprozessrecht 10 (1949). 
cedure (Zivilprozessordnung - hereinafter "ZPO"):

The presiding judge shall see to it that the parties make full explanations concerning all material facts and make the appropriate demands for relief, in particular that they supplement inadequate statements of asserted facts and designate sources of proof. For this purpose he shall, to the extent necessary, discuss the factual and legal aspects of the dispute with the parties and put questions.

This so-called "duty of clarification" (Aufklärungspflicht) requires the judge to assist the parties "in order to clarify the content of the parties' claims and their objectives in the litigation, to cause the parties to supplement their assertions and thus contribute to a proper disposition of the litigation." 45

The role of the attorney in the German litigation process is much more limited than that of his American counterpart. $\mathrm{He}$ is not clothed with authority to demand information, and, consequently, he cannot perform a significant investigative function. ${ }^{46} \mathrm{He}$ has access only to those facts that are presented to him or that he can ascertain on his own. Moreover, the fee system discourages fact investigation by generally not providing conpensation for it. ${ }^{47}$

The German attorney also has virtually no role in fact presentation. He makes available to the court information which is available to him and nominates sources of information which he believes will prove his client's factual claims, but he has little to do with the presentation of factual information. He may suggest questions for the judge to put to the witnesses and may even pose questions himself, but the extent of such questioning is quite limited, and it clearly plays a subsidiary role. 48

German procedure is thus centered on the judge. Control of proceedings by the judge in the interests of parties and witnesses is critical to the entire conception of the legal process. Therefore, allowing attorneys to utilize state power to search for information with virtually no supervision by the court conflicts with fundamental principles of the German procedural system. Consequently, a major source of resistance to the extraterritorial application of U.S. discovery methods is the authority such methods give to private attorneys and the lack of judicial supervision of the fact-gathering process.

45. Rosenberg \& Schwab, supra n. 44 at 437. For a discussion, see Baumbach \& Lauterbach, supra n. 39 at 430-35. See also Stuerner, Die Richterliche Aufklärung im Zivilprozess (1982).

46. See generally Kaplan, von Mehren \& Schaefer, supra n. 24 at 1199-1202.

47. See id. at 1200 .

48. Id. at 1235. 


\section{Treatment of Information}

The German and American procedural systems also treat information differently. In the United States, evidence is "gathered", "presented", and evaluated. The attorneys perform the first c two functions; the jury performs the third. In the German procedural system, evidence is "suggested" or "nominated" by the attorneys and "received" and evaluated by the court.

In the United States, the fact-gathering process is prior to, and separate from, the law-determination process. The result is that the system encourages attorneys to amass facts which tend to support any legal theories which may turn out to be relevant to the issues that eventually are identified as dispositive of the litigation. Moreover, decisions concerning discovery are placed in the hands of private attorneys whose incentives are to acquire as much information as possible.

Once evidence has been gathered, its presentation to the court is subject to extensive control by the attorneys. For example, the attorneys present the evidence themselves, and generally determine when and how "their" information is presented to the court. In addition, there is extensive attorney control over the form and manner of presentation of evidence, particularly with regard to the testimony of witnesses, because the attorney generally "prepares" the witness by questioning and discussions prior to his testimony and because testimony generally may be presented only in response to questions posed by the attorneys. Thus the presentation of information is continually subject to detailed control by the attorneys.

In Germany, in comparison, a court generally may compel the production of evidence only where one of the parties requests that particular evidence be compelled and can establish the likely relevance of such evidence to the litigation. ${ }^{49}$ The procedure for taking evidence is known as "evidence reception" (Beweisaufnahme), ${ }^{50}$ and,

49. There is a widespread impression in the United States that the German system is "inquisitorial" because the judge is primarily responsible for taking evidence. Recently, for example, one American expert stated that "In civil law countries, like Germany or France, an 'inquisitorial' not an 'adversarial' system of justice exists. Judges, not the parties or lawyers, do the questioning and taking of other evidence ...." Seidel, "Introduction and Overview," in Extraterritorial Discovery in International Litigation (Seidel ed. 1984). This fails to recognize the degree to which the judge is bound by the party-presentation principle.

An inquisitorial system was tried in Prussia from 1781 through 1833, but it was rejected in subsequent German legislation. See, e.g., Caenegem, "History of European Civil Procedure," in Civil Procedure, Vol XVI Int'l Encyc. Comp. L. 92-93.

50. The German "Beweisaufnahme" is generally translated as "evidence-taking", but this article generally avoids the term "taking of evidence" in reference to German civil procedure, because that term may suggest that the court's role is more assertive than it generally is. 
as the term suggests, it represents an essentially passive concept of the treatment of evidence.

The essentially passive posture of the German litigation process is also evident in the manner in which evidence-in particular, testimony-is received by the court. Very little control may be exercised over the form of testimony either by the court or by the attorneys; evidence is thus presented basically in "raw form". A witness is typically requested by the court to relate his knowledge of particular events or circumstances in a continuous narrative, ${ }^{51}$ and there is little interference with a witness' testimony. In general, questions are posed only at the conclusion of the narrative and only by the judge. An attorney may suggest or pose questions designed to reflect weaknesses in testimony, ${ }^{52}$ but the extent of such questioning is limited by the fact that it is the responsibility of the judge to probe for such weaknesses, and questioning by an attorney may tend to suggest that the judge is not meeting that responsibility. ${ }^{53}$

Thus, the American and German litigation processes treat information quite differently. In the U.S. the basic notion is that the litigation process-through private attorneys-is justified in compelling the production of extensive amounts of unspecified and detailed information and then manipulating such information for presentation to a trier of fact. In Germany, the basic notion is that information is to be compelled only where specified and demonstrated to be reasonably necessary for purposes of the litigation. Moreover, such information is to be presented in unmanipulated form to a professional judge. These differences reflect, therefore, a sharp conflict over the proper use of state power in relation to information.

\section{The Scope of Evidentiary Obligations}

Related to these differences in the treatment of evidence are differences in the scope of information subject to the litigation process. The differences here relate to the structure of obligations to provide information as well as to relevancy and confidentiality limits on the scope of such obligations.

\section{The Obligation to Provide Information: Basic Concepts}

The first issue is who may be compelled to provide what types

51. ZPO § 396. See also Kaplan, von Mehren \& Schaefer, supra n. 24 at 1235.

52. The permissible scope of an attorney's questions is limited. According to one commentator, the questions of an attorney "may . . . cover only the subject matter of the examination as stated in the evidence order. . . Judges rarely allow witnesses, in answer to questions by the attorneys, to cover ground already covered in answering the court's questions. Martens, "German Civil Procedure and the Implementation of the Hague Evidence Convention," 1 Int'l Litig. Q. 115, 120 (1985).

53. Kaplan, von Mehren \& Schaefer, supra n. 24 at 1235. 
of information, and the key distinctions are those between non-parties and parties and between testimony and document production.

In the U.S. the obligation of a party to provide information pursuant to the discovery process is extremely broad. ${ }^{54}$ A party may be deposed, and he may also be compelled to answer interrogatories and to produce documents. Thus, his obligation to provide information is subject only to the application of concepts of relevancy and confidentiality. ${ }^{55}$

The obligations of a non-party to provide information pursuant to discovery procedures are only somewhat more limited. In general, assuming that the court has jurisdiction over him, a non-party may be deposed, but he may not be compelled to answer interrogatories, nor is he subject to the essentially boundless obligation to produce documents which is applicable to parties. ${ }^{56}$ At the request of a party, a court may, however, issue a subpoena ordering a non-party to produce documents in conjunction with his deposition. ${ }^{57}$ Often, therefore, the scope of a non-party's obligation to produce documents is nearly as broad as that of a party.

At the trial, parties and subpoenaed non-parties are equally subject to a general duty to testify and to produce requested documents. This duty is subject only to rules of evidence which, in general, apply equally to parties and nonparties. ${ }^{58}$

In Germany, the structure of obligations to produce information for the litigation process is significantly different. Central to this structure is the fact that the rules applicable to parties are kept separate and distinct from those applicable to witnesses, and a party cannot be a witness (Zeuge). ${ }^{59}$

An initial set of evidentiary obligations relates to the party's presentation of his case. ${ }^{60}$ In presenting his claim for relief or his defense to the court, a party must provide assertions of fact to support his position on those issues as to which he bears the burden of proof. In addition, he must nominate evidence (Beweismittel) to

54. For a general description of the discovery process, see James \& Hazard supra, n. 28 at 223-270, and Haydock \& Herr, Discovery: Theory, Practice and Problems (1983).

55. See infra, text accompanying n. 84-89 and 93-96.

56. See generally, Friedenthal, Kane \& Miller, supra n. 29 at 407-08.

57. Fed R. Civ. P. 45. For discussion, see Welling, "Discovery of Nonparties: Tangible Things Under the Federal Rules of Civil Procedure," 59 Notre Dame L. Rev. 110 (1983).

58. For a general discussion of party and non-party assertion of privileges, see McCormick on Evidence, supra n. 36 at 153-54, and Republic Gear Co. v. BorgWarner Corp., 381 F.2d 551 (2d Cir. 1967).

59. For the development of the treatment of non-party witnesses in European law, see Nagel, supra n. 14 at 237-403.

60. For discussion, see Rosenberg \& Schwab, supra n. 40 at $439-40$. 
support his assertions of fact. ${ }^{61}$ This generally requires stating the name of the witness or describing the material to be examined by the court.62 If no evidence is nominated to support the assertion, it cannot be considered to have been proven.

In conjunction with this obligation to nominate evidence, the party also has a statutory "duty of truth" (Wahrheitspflicht) which includes a "duty of completeness". ${ }^{63}$ Accordingly, a party must recount all information relevant to his case accurately and completely, even where revelation of particular facts may be against his interest. Violation of this duty of completeness may result in criminal sanctions, and it may also constitute the basis for a damage claim against the violating party by his opponent. ${ }^{64}$

Some courts and commentators recently have extended the duty of completeness to apply in some situations to the party who does not bear the burden of proof. ${ }^{65}$ This allows a court to compel information from such a party concerning a particular assertion of fact, provided that the party bearing the burden of proof has demonstrated a reasonable likelihood that the asserted fact is true.

With regard to the taking of evidence by the court, the obligations of parties and non-parties are significantly different. A court may order a non-party to testify, in which case the witness must appear and testify accurately and completely in response to the questions of the court, and these duties may be enforced by fines and even jail sentences. ${ }^{66}$

A party may not, however, be compelled to testify. ${ }^{67}$ Until recently $^{68}$ parties were not even allowed to testify, the theory being that a party's testimony would be inherently biased and therefore

61. The term "nominate" translates the German "Beweisantreten", which literally means "entering of evidence". See Langbein, supra n. 41, at 834.

62. This is often done in what are sometimes called "pleadings", but it may also be done subsequently. For a description, see Martens, supra n. 52 at 118 . Examples of pleadings and other court documents may be found in Cohn, Manual of German Law 191-96 (2nd ed. 1971).

63. The duty of truth is contained in ZPO $\S 138 \mathrm{I}$, which provides that "The Parties shall make their declarations concerning factual circumstances complete and truthful." This critically important duty was based on a similar concept in the Austrian Code of Civil Procedure. See Bruns, Zivilprozessrecht 101 (2nd ed. 1979).

64. See Rosenberg \& Schwab, supra n. 60 at 378.

65. The key work in this development is Stuerner, Die Aufklärungspflicht der Parteien des Zivilprozesses (1976).

66. See Bruns, supra n. 63 at 282 .

67. Party testimony is provided for in ZPO $\S \S 445-455$. For discussion, see Arens, Zivilprozessrecht 213-14 (3rd ed. 1984) and Baumbach \& Lauterbach, supra n. 39 at 1081-89.

68. Parties were first permitted to testify under a revision of the ZPO enacted in 1933. Law of 27 Oct. 1933 [1933] IRGBL 780.

Party testimony replaced the use of the decisory oath and was based on the Austrian code. Rosenberg \& Schwab, supra n. 40 at 736 . For a discussion of the Austrian background, see Engelmann, supra n. 38 at 632-640. 
never useful to a court. ${ }^{69}$ The court may request that a party testify, but the court may make such a request only where no other evidence is available which can be used to evaluate an assertion of fact. ${ }^{70}$ Although a party is under no obligation to comply with such a request, the judge may draw inferences from a refusal to testify either in general or with respect to specific questions. ${ }^{71}$

The obligation to produce documents is considered separate and distinct from the obligation to testify, and it is subject to a separate set of rules. ${ }^{72}$ Here there are several important exceptions to the principle of party presentation. ${ }^{73}$ The court may, for example, of its own accord demand from any party the production of certain specified documents - e.g., commercial books of account-as well as any document to which such party may have made reference. ${ }^{74}$ In addition, the duty of completeness applicable to a party's presentation does not extend to the production of documents, ${ }^{75}$ and a party need not, therefore, submit documents in his possession which might tend to disprove his assertions of fact.

With regard to documents requested by a party, it is necessary to distinguish between two separate sources of documents. If a party seeks documents which are in the possession of his opponent, the opponent has an obligation to provide them to the court only if the materiality requirements for receiving evidence are met (discussed below) ${ }^{76}$ and if one of two additional conditions is fulfilled. First, if the opponent has referred to the existence of such a document in the context of the litigation (e.g., in the complaint), he must produce it. 77 Second, an opponent must produce a requested document wherever he is obligated to do so under provisions of substantive law. ${ }^{78}$ There are several important provisions of the civil and commercial law which create a right of information in the context of specific legal (generally, contractual) relationships. ${ }^{79}$ Consequently, a party may be entitled to request that documents be produced by his opponent, if, for example, such documents refer to a contractual relation-

69. For further discussion of the development and status of party testimony in Germany, see id. at 302-07.

70. ZPO § 451 .

71. Any such inferences are, however, entirely at the judge's discretion. ZPO $\S 446$.

72. ZPO $\S \S 418-431$. See generally, Nagel, supra n. 14 at 323-330.

73. See generally, Rosenberg $\&$ Schwab, supra n. 40 at 713 . The court may itself also demand documents from government sources. See, e.g., ZPO $\S 415$.

74. Some courts and commentators would extend this duty by implication to virtually any materials possessed by a party. See, e.g., Nagel, supra n. 14 at 343.

75. Baumbach \& Lauterbach, supra n. 39 at 428. Cf. Gottwald, Zur Wahrung von Geschäftsgeheimnissen im Zivilprozess, 35/36 BetriebsBerater, 1780, 3 (1979).

76. See infra, text accompanying n. 90-91.

77. ZPO § 423.

78. ZPO § 422 .

79.., These provisions are summarized in Rosenberg \& Schwab, supra n. 40 at 713. 
ship or negotiation between the two parties.80 If an opponent declines to produce a document which the judge believes to be in his possession, the judge may accept as proven the proponent's statements as to the content of such document. ${ }^{81}$ This substantive legal right to compel the production of documents has no close analogue in the United States system, and, therefore, its potential role in securing information generally goes unnoticed in the American literature.

If a document requested is in the possession of a nonparty, such person has an obligation to produce the document only under the circumstances discussed above concerning the opponent's obligation to produce documents. ${ }^{82}$ The only means of enforcing this obligation is, however, for the requesting party to file a suit against such person. ${ }^{83}$

In sum, the basic obligations to provide information for use in litigation are significantly more limited in Germany than they are in the United States, especially in regard to non-parties.

\section{Relevancy Limits}

Not only are the basic obligations to produce information more limited in Germany than in the United States, but the standard of relevancy is significantly higher in Germany. Because the relevancy issue has been particularly important in the controversy over extraterritoriality and because it has been the source of much confusion, it is necessary to be particularly careful in using the term. "Relevancy" will be used here to refer to limitations on the scope of evidentiary obligations which relate to the probability that particular information will contribute to accuracy in determing facts.

Under American procedure there are two standards of rele-

80. During recent years the courts have broadly interpreted the provisions of civil law which provide such an obligation. This has been particularly true with regard to section 810 of the BGB (Bürgerliches Gesetzbuch) which contains a general obligation relating to contractual negotiations. According to $\S 810$ :

Whoever has a legal interest in inspecting a document which is in the possession of another person, may demand from the possessor permission to inspect the document, provided that the document was made for his benefit or a legal relationship is documented between himself and another or the document describes negotiations relating to a transaction between him and another or between either of them and someone who is negotiating between them.

This provision has been held to create a substantive legal obligation to produce, for example, letters, receipts, and insurance policies. See Baumbach \& Lauterbach, supra n. 39 at $1065-66$.

81. ZPO § $427(2)$.

82. $\mathrm{ZPO} \S 429$.

83. ZPO $\S \S 429-431$. See Baumbach \& Lauterbach, supra n. 39 at 1069-1071. The court does not, however, possess any means of coercing the party to produce the documents. 
vancy, one for the discovery process and another for the trial. ${ }^{84}$ For purposes of this article, the discovery standard is the primary concern. ${ }^{85}$ According to Rule 26(b)(1) of the Federal Rules of Civil Procedure, discovery may be had whenever the "information sought appears reasonably calculated to lead to the discovery of admissible evidence." 86 The courts have interpreted this provision expansively. Only where the judge believes that the material sought bears no conceivable relationship to the subject matter of the litigation does the concept of relevancy limit the scope of the discovery process. ${ }^{87}$

Procedurally, the issue of relevancy comes before the court only where a party asks for a protective order limiting discovery, ${ }^{88}$ and the burden of persuasion is on the party opposing discovery. ${ }^{89}$ Consequently, attorneys routinely ask for all information which may bear on the subject matter of a litigation, and there is often little judicial scrutiny of the relevancy of discovery. ${ }^{90}$

The standard of relevancy in the German system is substantially higher than it is in the U.S. and significantly more complex. If a party nominates evidence to support an assertion of fact, the court must generally "receive" the evidence by ordering the designated person to testify or to produce the designated documents for inspection. This is subject, however, to two relevancy limitations-a standard of materiality ${ }^{91}$ and a procedural prerequisite of substantiation.

The materiality standard requires (1) that a material fact be at issue and (2) that the nominated evidence be material to the proof of such fact. A material fact is one which is itself an element of a litigant's claim or defense, and evidence may only be received with respect to the proof of such facts. ${ }^{92}$ Evidence is material to the proof

84. For a discussion of relevancy standards at trial, see 22 Wright \& Graham, Federal Practice and Procedure, §§ 5165, 6 (1978).

85. The stricter standard of relevancy applicable at trial need not be treated in this context, because the concern here is the scope of information which is subject to the litigation process.

86. Fed. R. Civ. P. 26(b)(1) reads, in relevant part, as follows:

Parties may obtain discovery regarding any matter, not privileged, which is relevant to the subject matter involved in the pending action. . . . It is not ground for objection that the information sought will be inadmissible at the trial if the information sought appears reasonably calculated to lead to the discovery of admissible evidence.

87. See 4 Moore's Federal Practice \|26.56[1] for examples.

88. This is done under Fed. R. Civ. P. 26(c).

89. Wright \& Graham, supra n. 84 at 264-65.

90. See, e.g., Byrnes, "Discovery: Its Uses and Abuses," 44 Antitrust L.J. 14, 25 (1975).

91. A material fact need not be proved, where, for example, it is a matter of common knowledge or it is included in a confession.

92. "'Material' includes anything which may influence the decision of the judge, that is, the consideration of which would lead to a determination which is different than the one which would have been reached without such consideration." Rosenberg \& Schwab, supra n. 40 at 570. 
of such a fact where it may reasonably be expected to influence the court's determination regarding such fact. A court will not receive evidence merely because it might lead in the direction of relevant information, as is the case in the U.S. Such evidence may only be received in order to affect the determination of whether an asserted fact is true. ${ }^{93}$

The requirement of substantiation provides a second relevancy limitation: a court may order testimony only where a party can generally describe the facts that the evidence is intended to prove. ${ }^{94}$ Where, for example, a plaintiff nominates evidence to prove that a conversation took place between $A$ and $B$, he must be in a position generally to describe where and when such conversation is likely to have taken place. Thus only where the party has a modicum of knowledge about the evidence to be taken as well as about the facts to be proven will a court order a witness to testify. The requirement of substantiation is designed to assure that evidence is taken only where the party nominating the evidence can show that taking such evidence is likely to yield information useful to the court. ${ }^{95}$

The German system thus places a substantial burden on any party seeking to utilize the state's power of coercion to secure information. One reason for this is to prevent waste of judicial time and effort and thus protect the efficiency and integrity of the system. ${ }^{96}$

Secondly, however, the relevancy requirements reflect a perceived need to protect individuals and businesses from excessive coercion by the state and from the concomitant compliance costs and interference with privacy rights that such coercion entails. ${ }^{97}$ Individual freedom is not to be interfered with and compliance costs are not to be imposed unless such actions can reasonably be justified as necessary to obtain justice..$^{98}$ Mere speculation of a party that a witness may say something relevant to the litigation process is not enough to trigger the use of state power.

93. In the extraterritorial discovery controversy the concept of materiality has often been misunderstood to be the only relevancy standard, in part, at least, because the German term for this standard (Erheblichkeit) is often translated as "relevancy" and American lawyers, unaccustomed in their own system to other types of relevancy limits, merely assume that this is the only relevancy standard.

94. See generally, Peters, Ausforschungsbeweis im Zivilprozess 12-16 (1966).

95. Relevancy limits are usually viewed as protection against "Ausforschung", which may be roughly translated as "probing". The main notion here is that the litigation system may not be used to "probe" for evidence. If a party does not have sufficient knowledge on which to base his claim, he has no right to use the litigation process to help him look for it. See Stuerner, supra n. 65 at 106-112.

96. See Peters, supra n. 94 at $63-65$.

97. See Stuerner, supra n. 65 at 114-16.

98. For discussion of this point in the context of the controversy over extraterritorial discovery, see infra, text accompanying n. 188. 


\section{Confidentiality Limits}

Confidentiality restrictions on the scope of information which can be subjected to the litigation process establish spheres of protected privacy for persons, organizations and relationships. ${ }^{99}$ Where a sphere of protection is created by state A, and a foreign legal system encroaches on that protected area, there is likely to be resistance to such encroachment. Since, therefore, Germany generally provides greater confidentiality protections than does the U.S., confidentiality issues have become a significant part of the controversy.

In Germany there are two basic sets of privileges (Zeugnisverweigerungsrechte) on the basis of which such a witness may withhold testimony. The first set includes privileges based on the nature of the relationship between the witness and the facts sought-e.g., family relationships or confidential professional relationships such as doctor-patient and attorney-client. ${ }^{100}$ These are similar to privileges in the U.S. The second set includes, however, the protection of many types of personal information-e.g., nonpublic business or artistic information and information which might bring dishonor or direct economic loss to the witness. ${ }^{101}$ The latter set of privileges often extends beyond protections available in the U.S. and thus leads to conflict.

The conflict has centered on one main area of difference between the German and American systems-the protection of business information. ${ }^{102}$ In the U.S. the protection of business or trade secrets in litigation is often quite limited. ${ }^{103}$ According to Rule 26(c)

99. The German system of privileges tends to focus on the recognition of personal or organizational "privacy spheres", whereas in the United States, confidentiality protections relate primarily to relationships-such as, for example, doctor-patient or attorney-client. For a discussion of common law concepts of privilege, see McCormack on Evidence, supra n. 36 at 170-187.

100. ZPO $\S \S 383,384$. See also Rosenberg \& Schwab, supra n. 40 at $718-19$, and Kaplan, von Mehren \& Schaefer, supra n. 24 at 1237-39.

101. ZPO $\S \S 384,5$.

102. See, e.g., Schlosser, Internationale Rechtshilfe und Rechtsstaatlicher Schutz von Beweispersonen, 94 Zeitschrift für Zivilprozess 369 (1981).

103. The term "trade secret" in U.S. law is generally used as a term of art relating to specific types of (usually) technological information. According to one leading definition:

The term 'trade secret' as it is usually understood means a secret formula or process, not patented, known only to certain individuals who use it in compounding or manufacturing some article of trade having a commercial value. It is rarely, if ever, used to denote the mere privacy with which an ordinary commercial business is carried on.

In re Bolster, 59 Wash. 655,110 P. 547, 548 (1910). There are significant variations in the definition of trade secrets. For a discussion, see Milgrim, Trade Secrets $\S 2.01$ (Vol. 12, Business Organizations 1985).

In Germany, the notion of "business secret" (Geschäftsgeheimnis) is much broader and relates to any type of business information. See infra, text accompanying $\mathrm{n}$. 111-13. 
of the Federal Rules of Civil Procedure, a party or witness may apply to the court for a protective order directing "that a trade secret or other confidential information not be disclosed or be disclosed only in a designated way."104 This provision permits a witness or party to seek to limit the use of discovery procedures to gain access to its business secrets. If the judge considers the request justified, he may allow the person requesting protection to decline to provide such information or order that he provide it in a way which limits access to it. ${ }^{105}$

The judge is given virtually unlimited discretion to determine when protection should be provided. Moreover, a protective order often has only a temporary effect, because even information protected during discovery frequently must be revealed at trial. ${ }^{106}$

In Germany the protection of business information is much broader in scope, and such information is protected during the entire proceeding rather than only temporarily. ${ }^{107}$ Access to business information in litigation depends on who has the information sought and who is sought to be excluded from access to such information. ${ }^{108}$ The judge may exclude the public from proceedings relating to certain information, including business secrets, "whose public discussion would violate predominant interests deserving protection."109 Thus, exclusion is likely wherever the presence of the public might harm a significant business interest. ${ }^{110}$

More difficult is the issue of whether the information must be disclosed in the court proceedings. Here the distinction between parties and witnesses becomes particularly important. According to Section 384(3) of the ZPO, a witness has a right to refuse to answer questions "that the witness would not be able to answer without revealing a . . . business secret." A "business secret" for these purposes may be any information which is not public and which an

104. "To resist discovery, the party must establish that the information is a trade secret within the definition of Rule 26(c)(7)(2), and that its release might be harmful," 4 Moore's Federal Practice If 26.60[4].

Protection may also be available under state law, but the degree of protection varies significantly. See generally, Protecting Trade Secrets 1985 (Pretty ed. 1985).

105. For a discussion of such protective procedures, see Milgrim, Trade Secrets, I 7.06[1][c]-[e] (Vol. 12A, Business Organizations 1985) and 4 Moore's Federal Practice, I 26.67 .

106. See Milgrim, supra n. 105 at $\S 7.06[2]$ ][3]. See also, e.g., Kleinerman v. U.S. Postal Service 100 F.R.D. 66 (D. Mass. 1983).

107. Under German law, confidentiality provisions protect against incursion by the litigation process into defined spheres of privacy and thus do not vary according to the stage of the proceeding.

108. See Gottwald, "Zur Wahrung von Geschäftsgeheimnissen im Zivilprozess," 35/36 BetriebsBerater, 1780, 3 (1979).

109. $\S 172$, Statute on the Organization of Courts (Gerichtsverfassungsgesetz). For discussion, see Baumbach \& Lauterbach, supra n. 39 at 2164-65.

110. Gottwald, supra n. 108 at 1781. 
enterprise has a legitimate interest in protecting. ${ }^{111}$ This may include product information as well as information on marketing and enterprise strategy. ${ }^{112}$ There is no doubt that this covers the witness' own business secrets, ${ }^{113}$ although there is conflict concerning its application to the business secrets of others. ${ }^{114}$

Another provision of the ZPO normally justifies a witness in refusing to disclose information with regard to the business secrets of others. According to Section 383, I(6), persons "who by virtue of their ... business have information confided to them whose secrecy is required by its nature or by statute. . . ." may decline to disclose information. Thus, where a witness learns of information by virtue of a confidential relationship, such as employer-employee or distributor-manufacturer, he is justified in not testifying with regard to such information. ${ }^{115}$ The combined effect of these two sections is that witnesses are generally justified in refusing to provide nonpublic business information.

There is also little opportunity for a party to compel his opponent to divulge business secrets, because the opponent generally has no obligation either to testify or to produce documents. Those courts which have extended the parties' duty of completeness to parties who do not have the burden of proof have, however, required some business secrets to be revealed under a balancing test, 116 according to which the court must weigh the defendant's need for secrecy against the plaintiff's need for information. ${ }^{117}$

In general, therefore, business information is given substantially more protection in Germany than in the U.S., and this protection is justified, in large part, by the perceived need to prevent firms from utilizing the litigation process to gain access to business secrets. In the context of extraterritorial discovery the need for such protection takes on an added dimension because the relatively weak protection of business secrets in the U.S. may permit American (or other) busi-

111. According to one commentator, "'Trade secret' (Gewerbegeheimnis) can . . be anything which by its nature may be in the interest of a business to keep secret." Schlosser, supra n. 102 at 402.

112. See Gottwald, supra n. 108 at 1781.

113. See, e.g., Bruns, supra n. 41 at 288.

114. See Gottwald, supra n. 108 at 1781.

115. See Baumbach \& Lauterbach, supra n. 39 at 1019-23.

116. This is part of the controversy over whether, and when, parties without the burden of proof have an obligation to provide information. See supra, text accompanying n. 65 .

117. The basic principle appears to be that the secrecy interest must be subjugated to the information interest only to the extent necessary for the court to evaluate an assertion of fact which the plaintiff has been able to demonstrate is reasonably likely to be true. See generally, Gottwald, supra n. 108 at $1782-83$, and cases cited therein. Some commentators would also require documents to be produced under such circumstances, but this remains a minority position. 
nesses to employ the litigation process to coerce foreign business information. ${ }^{118}$

\section{E. Concepts of Procedural Justice}

Underlying each procedural system is a structure of concepts of procedural justice whose interrelationships are determined by the relative value attached to each by the society in which the system operates. The differences between the U.S. and the German procedural systems reflect differences both in concepts of procedural justice and in the values attached to such concepts.

Two interrelated concepts of procedural justice are central to the American system. The first is that competition between attorneys tends to produce fairness and justice-the so-called adversarial principle. ${ }^{119}$ According to one commentator:

". . the experienced judge or arbitrator desires and actively seeks to obtain an adversary presentation of the issues. Only when he has had the benefit of intelligent and rigorous advocacy on both sides can he feel fully confident of his decision.

Viewed in this light, the role of a lawyer as a partisan advocate appears not as a regrettable necessity, but as an indispensible part of a larger ordering of affairs. The institution of advocacy is not a concession to the frailties of human nature, but an expression of human insight in the design of a social framework within which man's capacity for impartial judgment can attain its fullest realization. ${ }^{120}$

In this view it is the nature of the adversarial process itself which leads to justice.

In the U.S. the adversarial principle is intertwined with a second key notion-namely, that maximum access to facts is necessary for the provision of justice. The common law tradition, ${ }^{121}$ fortified by ideas of "legal realism" and of process theory, ${ }^{122}$ has engendered a strong belief in the necessity of maximum access to facts. As stated by the U.S. Supreme Court in Hickman v. Taylor, "mutual

118. See generally, von Huelsen, supra n. 1.

119. For recent discussions of the adversarial principle in the context of the American system, see, e.g., Landsman, The Adversary System (1984) and Miller, "The Adversarial System: Dinosaur or Phoenix?," 69 Minn. L. Rev. 1 (1984). For discussion of the relationship between discovery and the adversary system, see Glaser, supra n. 21 at 34-37.

120. Gray, The Nature and Sources of Law 115 (2d ed. 1921), cited in Fuller, supra n. 34 at 384 .

121. See generally, Landsman, supra n. 119 at 8-26.

122. See generally, Purcell, supra n. 20 at 74-94, 159-79, and White, "From Sociological Jurisprudence to Realism: Jurisprudence and Social Change in Early Twentieth-Century America," 58 Vir. L. Rev. 999 (1972). 
knowledge of all the relevant facts gathered by both parties is essential to proper litigation. To that end, either party may compel the other to disgorge whatever facts he has in his possession." 123 It is this concept which justifies the use of state power to coerce the production of information for use in the litigation process. The combined influence of these justice concepts has impelled the system toward a highly activist view of the litigation process and a dominant role for attorneys in that process. Moreover, during the last half century this configuration of justice concepts has dominated legal thinking to the exclusion of other concepts of justice. Until very recently, values which would limit the scope of the litigation process have seldom had significant influence.

The German system is also based on the adversarial principle, ${ }^{124}$ but it is not accompanied by the maximum fact access principle which has been so dominant in the United States. There is no assumption that justice is likely to be directly proportional to the access of the parties to facts. Indeed, it is the ability of the system to focus on determining those facts which are relevant to the legal issues that is considered critically important.

In addition, however, there are two concepts of procedural justice that tend to limit the influence of the adversarial principle. The first may be called the concept of judicial professionalism.125 According to Professor Karl Larenz:

The judge, who in modern procedural law must "freely" assess the elements of proof, must conscientiously convince himself concerning the facts, while eliminating all sources of error which are known to him. It is not possible here to dispense with human personality and a method of evaluation which is carefully formed by the judicial ethos. ${ }^{126}$

The central notion is that procedural justice is primarily secured by the informed professionalism of the judiciary. It is the judge's skill and experience in evaluating evidentiary material which is considered likely to lead to the "truth", not the gathering of immense quantities of factual information by attorneys who are then free to

123. Hickman v. Taylor, 329 U.S. 495, 507 (1947).

124. This is certainly true if one functionally defines the adversarial principle so as to refer to the basic allocation of incentives and responsibilities in the system. In this view a system based on the adversarial principle is one in which the parties are primarily responsible for presenting the elements of a civil conflict to the court and in which competition between parties or their representatives is the basic mechanism for achieving effectiveness in the resolution of the conflict.

125. See generally, Shapiro, Courts: A Comparative and Political Analysis 150-53 (1981) and Meador, "German Appellate Judges: Career Patterns and American-English Comparisons," 67 Judicature 16 (1983).

126. Larenz, Methodenlehre der Rechtswissenschaft 293 (5th ed. 1983). 
present or not to present such information and to manipulate its presentation to serve their own ends.

Moreover, it is the close interrelationship of the fact-determination process with the law-determination and law-application functions which allows the judge effectively and efficiently to reach a just result. The keystone of the legal process is the proper application by a professional judge of a body of concepts to a given fact pattern. The judge's ability to apply such principles correctly is the central value in the process.

The German legal system is built around this notion. Unlike American judges, German judges are career civil servants who are trained as judges immediately after finishing their legal training and remain judges throughout their lives. The judicial profession is the only profession with which most will be associated, and the system contains important incentives for the maintenance of professional quality and of high standards conduct. It is the professionalism engendered by this incentive-based collegial structure which is expected to assure impartiality as well as thoroughness.

A second central concept of procedural justice may be called the "classical liberal" theory of the litigation process. The idea is that the litigation process is intended to be a means of resolving disputes in society with the maximum dispatch, a minimum of interference with private rights and a minimum cost to society. Accordingly, the state is not to be allowed to interfere with privacy rights or impose burdens on private citizens for the sake of the resolution of a private conflict unless there is a reasonable basis for believing that the result of such use of state power will be significant.

Thus, the differences between the litigation process in the U.S. and Germany reflect differing concepts of procedural justice and differing configurations of values attached to such concepts. Consequently, procedures that are fundamental to fairness in one system may, if imposed on the other system, violate fundamental notions of justice and fairness. Where American discovery rules are applied to conduct in Germany, there is a direct confrontation between the values embodied in the two systems.

\section{The Controversy Over Extraterritorial Discovery}

\section{A. Approaches to Extraterritorial Evidence}

There are significant differences between the United States and Germany regarding both the legal mechanism for dealing with extraterritorial evidence and the approach to the issue itself. These differences constitute the immediate context of the controversy over extraterritorial discovery.

In the U.S., discovery rules are often assumed to be applicable 
in the same manner to foreign evidence as to domestic evidence, provided that discovery does not exceed any limits that might be imposed by domestic or international law. As a result, the concept of international judicial assistance, whereby a domestic court requests that evidence outside the country be "taken" by a foreign court and transmitted for use to the domestic court, generally receives little attention in the U.S. ${ }^{127}$ Moreover, such procedures tend to be mistrusted by American attorneys, for they appear to violate basic American concepts of procedural justice by interfering with free access to evidence and by requiring a different evidentiary procedure than is applicable to domestic evidence. ${ }^{128}$

In Germany, the structure of the system and the values embodied in it impel a different legal framework for extraterritorial evidence. Where evidence is located outside of the country, German law automatically turns to the procedures of international judicial assistance to seek to acquire such evidence. ${ }^{129}$ Since it is the judge who "receives" evidence in domestic procedure, it is natural for a civil law system to look to a cooperative arrangement between judges to secure evidence outside the country.

International judicial assistance is, therefore, the automatic and necessary frame of reference for extraterritorial evidence-taking. Moreover, there is an established body of law which deals with the procedures relating to international judicial assistance and with the rights and obligations applicable to that process.

Thus, the two systems approach the issue of extraterritorial discovery from differing starting points. The German literature on the controversy tends to focus on issues relating to international judicial assistance, ${ }^{130}$ and especially the role of the Hague Evidence Convention, whereas the American discussion of the subject tends to focus

127. A personal survey of textbooks and casebooks currently in use in United States law schools reveals that the concept of international judicial assistance is virtually never mentioned.

128. One of the main problems here is the fact that U.S. rules concerning the admissibility of evidence at trial often make the use of evidence obtained abroad under foreign procedures difficult, marginally effective or even impossible. For discussion, see Seidel, "United States Trial Considerations When Obtaining Evidence Abroad," in Seidel (ed.), Extraterritorial Discovery in International Litigation 429 (1984).

129. International Procedural Law (Internationales Prozessrecht) is a well-defined area of law, a major part of which deals with international judicial assistance. Leading treatises include Nagel, Internationales Prozessrecht (1980) and Schuetze, Internationales Prozessrecht (1980).

130. See, e.g., Mentz, "Das Pre-Trial Discovery Verfahren," 27 Recht der Internationalen Wirtschaft 73 (1981); von Huelsen, "Vorlage von Dokumenten and Zeugen Vernehmungen fuer US-Zivilprozesse (PreTrial Discovery)," Recht der Internationalen Wirtschaft 315 (1974); Schlosser, supra n. 102; and Stuerner, "Die Gerichte and Behörden der USA and die Beweisaufnahme in Deutschland," 81 Zeitschrift für Vergleichende Rechtswissenschaft 159-214 (1982). 
on the application of American legal rules to foreign evidence. ${ }^{131}$

\section{B. Extraterritorial Discovery Under Domestic Law}

The domestic laws of each country relating to extraterritorial evidence play an important role in the controversy by providing the conceptual framework through which each side views the conflict and by establishing the parameters of response by each side to actions of the other.

American courts have generally taken the position that discovery procedures applicable to domestic discovery are also applicable where foreign evidence is concerned, except where prohibited by international law or restricted by domestic concepts reflecting international concerns. ${ }^{132}$ This framework of analysis is based on the interplay of three sets of legal concepts.

The discovery rules themselves provide the first component of the argument. U.S. discovery rules generally do not specify the geographical scope of their application, and, with limited exceptions, they do not specifically refer to international evidence issues. ${ }^{133}$ As a result, litigants and courts often assume that since the statutory language does not limit the geographical scope of the discovery provisions, they are applicable on a worldwide basis. ${ }^{134}$

Secondly, the concept of personal jurisdiction is viewed as conferring power on the court. ${ }^{135}$ Consequently, if a court has jurisdiction over parties or witnesses, the assumption is that it is authorized to make whatever orders it thinks proper with respect to such persons, provided that it does not thereby violate constitutional or other

131. See, e.g., Acomb, "Foreign Depositions: The Problems, Pitfalls and Procedures," 14 Forum 440-458 (1979); Light, "Discovery Abroad and the Consequences When Recovery is Not Possible," 50 Antitrust L.J. 577-98 (1982); Carter, "Obtaining Foreign Discovery and Evidence for Use in Litigation in the U.S.: Existing Rules and Procedures," 13 Int'l Lawyer 5-18 (1979), Platto, "Taking Evidence Abroad for Use in Civil Cases in the United States-A Practical Guide," 16 Int'l Lawyer 575-585 (1982). For a useful bibliography, see McKay, "Compelling Discovery and Disclosure in Transnational Litigation: A Selected Bibliography," 16 N.Y.U.J. Int'l L. \& Pol. 1217 (1984).

132. See infra, text accompanying n. 139-47 and 158-72.

133. The following provisions of the Federal Rules relate specifically to foreign discovery: 28(b), 32(b), 44(c)(2) and 45(e)(2).

134. In other areas, however, the U.S. Supreme Court in recent years has specifically rejected this assumption. The Court has emphasized that international situations may require that U.S. laws be applied in a manner which differs from their application in purely domestic cases. See, e.g., Bremen v. Zapata Offshore Corp., 407 U.S. 1 (1972) and Mitsubishi Motors Corp. v. Soler Chrysler-Plymouth Inc., 87 L.Ed. 244 (1985).

135. According to Kaplan, von Mehren \& Schaefer: "We venture the observation that the German system for allocating business among the courts is best learned when one first forgets American conceptions of 'jurisdiction over the person' and of 'territorial limits of effective service.'" Supra n. 24 at 1205. 
norms. ${ }^{136}$ In the context of extraterritorial discovery, therefore, the power concept of jurisdiction creates a presumption of authorization. ${ }^{137}$

The third concept supporting this jurisdictional assertion is one of parallelism. Since a foreign litigant in an American court has the right to utilize American discovery methods to investigate the facts of the case, it would be unfair to his domestic opponent not to permit equivalent discovery opportunities with regard to him, regardless of the location of the information. ${ }^{138}$

These factors tend to impel United States courts to apply discovery rules extraterritorially. Consequently, on the basis of one or more of these concepts, U.S. courts have generally found that they were authorized to apply U.S. discovery rules to foreign evidence, except where prohibited by certain domestic or international legal principles.

Two related domestic legal concepts are used to limit extraterritorial discovery. The first such source of limits is the doctrine of foreign government compulsion. ${ }^{139}$ An American court generally will not compel the violation of a duty which is statutorily imposed by a foreign government relating to action within the territory of such state, at least where such violation would lead to criminal liability. ${ }^{140}$ Thus where a state imposes criminal liability for providing domestic documents for use in foreign investigations or foreign litigation, American courts have held that this statutory provision must generally be given force and that a party or witness failing to produce evidence because of it may not be penalized in American litigation. ${ }^{141}$

Recent American cases have, however, attached a substantial limitation to this defense, holding that it is only applicable where the party claiming its benefit has made a good faith effort to secure

136. See generally, In re Anschuetz \& Co., 754 F.2d 602, 614 (5th Cir. 1985).

137. Critical here is the framing of the issue. Where the issue is viewed as one of judicial power, the judge is likely to be compelled by notions of fairness to the domestic litigant to exercise that power, unless there is a legal principle limiting the court's power.

138. See In re Anschuetz \& Co., 754 F.2d 602, 606 (5th Cir. 1985).

139. The foreign government compulsion concept is generally not viewed as deriving from public international law. It is, rather, a doctrine of United States law based on notions of procedural fairness to litigants as well as notions of international comity.

140. For general treatments of the doctrine, see Meal, "Government Compulsion as a Defense Under United States and European Economic Community Antitrust Law," 20 Colum. J. Transnat l L. 51 (1981) and Note, "Development of the Defense of Sovereign Compulsion," 69 Mich. L.Rev. 888 (1971).

141. The existence of such a statutory provision does not constitute a defense unless there is a high probability that the provision will be enforced. See, e.g., Compagnie Française D'Assurance Pour le Commerce Exterieur v. Phillips Petroleum Co., 105 F.R.D. 16 (S.D.N.Y. 1984). 
exemption from the provisions of the statute. ${ }^{142}$ Thus in Graco Inc. $v$. Kremlin, Inc., ${ }^{143}$ a U.S. district court ordered a French defendant to comply with discovery requests which appeared to violate a French blocking statute that imposed penalties for providing documents for use in foreign litigation. In assessing the sanctions it would apply in the event of a failure to comply with its discovery order, the court said it would

... inquire whether SKM is relying on the Blocking Statute in good faith, or whether it has not made a genuine effort to determine whether it might comply with the court's order despite the Blocking Statute. Such a genuine effort might include exploration of several possibilities, such as: securing an exemption from France; complying with as much of the court's order as possible outside the territorial reach of the Blocking Statute; effecting as much compliance as possible under the procedures of the Hague Convention; and providing the court with a firm basis for understanding the manner in which France enforces its Blocking Statute. ${ }^{144}$

As limited by this good faith requirement, the foreign government compulsion defense may have little impact on the scope of extraterritorial discovery.

The second domestic limitation on the reach of extraterritorial discovery is the concept of comity. ${ }^{145}$ According to this principle, American courts must take into account foreign interests when deciding whether to apply or enforce provisions of American law. In the context of extraterritorial discovery, some courts have used the concept in determining whether to order extraterritorial discovery and whether sanctions should be applied in the event of failure to obey such orders. ${ }^{146}$ Moreover, several courts have used the principle of comity to require that the procedures of the Hague Evidence Convention be followed before a court may order the use of American discovery procedures. ${ }^{147}$

Under German law the issue of extraterritorial discovery is analyzed quite differently. The American notion that personal jurisdiction subjects parties and witnesses to the power of the court and thus implicitly creates a presumption of authority over them is un-

142. See generally, Meal, supra n. 140 at $67-82$.

143. 101 F.R.D. 503 (N.D. Ill. 1984).

144. Graco Inc. v. Kremlin, Inc., 101 F.R.D. 503, 526 (N.D. Ill. 1984).

145. See generally, Yntema, "The Comity Doctrine," 65 Mich. L. Rev. 9 (1966) and Maier, "Extraterritorial Jurisdiction at a Crossroads: An Intersection Between Public and Private International Law," $76 \mathrm{Am}$. J. Int'l L. 280 (1982).

146. See, e.g., Ings v. Ferguson, 282 F.2d 149 (2d Cir. 1960).

147. See, e.g., Laker Airways, Ltd. v. Sabena, Belgian World Airlines, 731 F.2d 909 (D.C. Cir. 1984) and Schroeder v. Lufthansa German Airlines, 18 Av. Cas. (CCH) ף 17,222 (N.D. Ill. 1983). 
known in German law. The term "personal jurisdiction" is not even easily translated into German, because there is no nearly analogous concept. ${ }^{148}$ In Germany, particular courts are "competent" (zuständig) to resolve certain kinds of disputes. ${ }^{149}$ When a suit is filed before a competent court, that court may make certain well-defined and statutorily-authorized orders with respect to parties and witnesses, and failure to comply with its orders may entail sanctions. There is, however, no notion that particular contacts of parties or witnesses with the forum give that court broad and undifferentiated power with respect to such persons.

The limiting concepts of foreign government compulsion and comity are also without direct analogue in German law. Instead, domestic law restraints are derived from the principles of private international law which determine whether a foreign law may be applied by a German court and whether a foreign judgment may be recognized by a German court. 150

Thus, the two systems differently conceive the legal issue presented by extraterritorial discovery. In the U.S. the issue is one of judicial power-whether a U.S. court has the power to require certain actions. In Germany, the issue is generally considered to be the validity of applying legal norms-here, American discovery rules-within German territory.

The principle of private international law that is most significant in the context of international discovery is that of "ordre public". ${ }^{151}$ A court may decline to apply a particular foreign law or to recognize a foreign judgment if such action would violate "fundamental principles of the legal order". ${ }^{152}$

The concept of ordre public is relevant to the extraterritorial discovery conflict in two ways. First, it serves as the basic conceptual reference-point for assessing the validity of U.S. discovery orders relating to conduct in Germany. Accordingly, if an American discovery order violates fundamental principles of the German legal order, it cannot validly be applied to conduct within Germany.

Since, however, an American court applying American discov-

148. See generally, Gerber, "The Extraterritorial Application of the German Antitrust Laws," $77 \mathrm{Am}$. J. Int'l L.756, 760 (1983).

149. See generally, Cohn, supra n. 62 at 170-73.

150. See, e.g., Dolle, Internationales Privatrecht $(2 \mathrm{~d}$ ed. 1972).

151. "Ordre public" is often translated as "public policy" in English-language literature. For discussions, see Kahn-Freund, General Problems of Private International Law 282-85 (1980); Paulsen \& Sovern, "Public Policy in the Conflict of Laws," 56 Col. L. Rev. 969 (1956); and Forde, "Ordre Public," 29 Int'l \& Comp. L.Q. 259 (1980).

152. The basic concept is contained in Art. 30, Einführungsgesetz zum Bürgerlichen Gesetzbuch (EGBGB), according to which "a foreign law will not be applied if this would violate bonos mores or the purpose of a German statute." For discussion, see Cohn, supra n. 62 at 103-07. 
ery rules is not asking a German court to apply foreign law within its borders, the only context in which this "violation" of Germany's ordre public can be attacked under German law is in relation to the recognition of an American judgment based on such "invalid" discovery.

According to Section 328(4) of the ZPO, a German court may refuse to enforce a foreign judgment if recognition of the judgment would violate ordre public principles. ${ }^{153}$ Thus, if a United States court orders discovery that is considered to violate German ordre public principles, any U.S. judgment based on, or related to, such a discovery order may thereby be rendered unenforceable under German law. ${ }^{154}$ The fact that these differences between U.S. and German procedural principles might lead to failure by German courts to recognize U.S. judgments does not yet appear to have played a role in American discussions of extraterritorial discovery.

There do not as yet appear to be any reported cases dealing specifically with the application of ordre public principles to U.S. discovery orders. ${ }^{155}$ Scholarly opinion, as well as government statements, however, view U.S. discovery orders relating to conduct on German soil as violations of German ordre public principles, at least under certain circumstances. ${ }^{156}$ According to one commentator:

The sometimes crass value differences in substantive law [between the United States and Germany] are so significantly exacerbated by the peculiarities of American procedural law, with its private investigatory rights and decision by the jury, that aid in applying American law must in many cases be classified as a violation of ordre public principles. ${ }^{157}$

\section{Relevance of Customary International Law}

The potential role of customary international law in the extra-

153. See generally, Rosenberg \& Schwab, supra n. 40 at 952-63.

154. Such a judgment may, of course, be enforceable against the defendant's assets located in the U.S.

155. There is one reported German appeals court decision in which a German court applied ordre public principles to a request by a U.S. court for judicial assistance under the Hague Evidence Convention. The court indicated that such requests might violate German ordre public principles under some circumstances, but it did not find such a violation where the requested examination of witnesses would be conducted by a German judge and the procedural protections of the German system were available. Judgment of 27 Nov. 1980, Oberlandesgericht, Munich, 1981, 27 Recht der Internationalen Wirtschaft 554 (1981).

156. See, e.g., Stiefel, “'Discovery'-Probleme und Erfahrungen im Deutsch-Amerikanischen Rechtshilfeverkehr," 25 Recht der Internationalen Wirtschaft 509, 514520 (1979).

157. Von Huelsen, supra n. 1 at 550. 
territorial discovery context has not been thoroughly analyzed either in the U.S. or in Germany. In both countries, arguments based on customary international law have been based largely on assumptions about the content of general principles, in particular, the concept of territorial sovereignty. ${ }^{158}$ Each country recognizes that the concept of sovereignty provides certain limits on the scope and enforcement of U.S. discovery orders, but there are significant differences between the two countries concerning the content of such limits. ${ }^{159}$

American decisions have generally recognized that the concept of sovereignty prohibits the U.S. from ordering discovery within foreign territory-whether implemented by government officials or by attorneys acting under the authority of discovery rules. ${ }^{160}$ It has been held, for example, that an American court may not order a foreign national on foreign territory to allow inspection of documents or to submit to depositions, at least where the foreign state objects to such practices. ${ }^{161}$

American courts have generally held, however, that the principle of sovereignty does not prevent a U.S. court from ordering a foreign party or witness located in Germany to present himself and/or documents located in Germany for discovery in the U.S. and imposing sanctions against such party or witness for failure to comply with such order. ${ }^{162}$ The courts thus distinguish between ordering acts on foreign soil which are part of the U.S. litigation process-e.g., depositions-and ordering acts in foreign territory which are merely in preparation for the litigation process-e.g., boarding a plane for the United States.

Because the scope of the principle of sovereignty is a major factor in the conflict over extraterritorial discovery, it is important to ask why American courts have drawn the line so as to prohibit discovery which would take place in Germany, but not to prohibit an

158. For a discussion of the concept of sovereignty in the context of the issue of extraterritoriality, see generally Gerber, supra n. 5 .

159. A special feature of U.S.-German legal relations relating to the gathering of foreign information is an exchange of diplomatic notes according to which each country agrees to allow diplomatic officials of the other country to take evidence in their territory under specific conditions. See Exchange of Notes between United States and Fed. Rep. of Germany, T.I.A.S. No. 9938 (11 Feb. 1955; 13 Jan. 1956; 8 Oct. 1956; 17 Oct. 1979).

160. See, e.g., In re Anschuetz \& Co., 754 F.2d 602 (5th Cir. 1985).

161. See, e.g., Graco Inc. v. Kremlin, Inc. 101 F.R.D. 503 (N.D. Ill. 1984).

162. See, e.g., In re Anschuetz \& Co., 754 F.2d 602, 615 (5th Cir. 1985); Graco Inc. v. Kremlin, Inc., 101 F.R.D. 503 (N.D. Ill. 1984); McLaughlin v. The Fellows Gear Shaper Co., 102 F.R.D. 956 (E.D. Pa. 1984); Adidas, Ltd. v. S.S. Seatrain Bennington, 80 Cir. 1911, 82 Cir. 375, Slip Op. (S.D.N.Y. May 30, 1984); Slauenwhite v. Bekum MaschinenFabriken GmbH, 104 F.R.D. 616 (D. Mass. 1985); In re Messerschmitt Bolkow Blohm GmbH, 575 F.2d 729 (5th Cir. 1985); In re Societe Nationale Industrielle Aerospatiale, 85 Civ. 2306, Slip Op. (8th Cir. 22 January 1986). 
American court from ordering a person to leave Germany or to send documents out of Germany for discovery purposes. A key factor appears to be the role of "judicial sovereignty".

This concept, as used in the present context, ${ }^{163}$ seems to have derived from the report of the U.S. delegation to the conference which prepared the Hague Evidence Convention. ${ }^{164}$ According to that report:

The act of taking evidence in a common law country from a willing witness, without compulsion and without a breach of the peace, in aid of a foreign proceeding, is a purely private matter, in which the host country has no interest and in which its judicial authorities have normally no wish to participate. To the contrary, the same act in a civil-law country may be a public matter, and may constitute the performance of a public judicial act by an unauthorized foreign person. It may violate the "judicial sovereignty" of the host country, unless its authorities participate or give their consent. ${ }^{165}$

The concept of judicial sovereignty was then used in several American cases for the same basic purpose-i.e., to explain the assertion by foreign governments that U.S. discovery practices violated sovereignty rights. ${ }^{166}$ In these cases the U.S. courts used the concept to explain how what the U.S. considered an essentially private act could violate the sovereign rights of a foreign nation.

Having been used to explain that proposition, however, the concept acquired a life of its own, and it has recently been used to perform a different function-namely, to determine the scope of the concept of sovereignty. For example, in one recent U.S. district court case the court held that French sovereignty was not infringed by a U.S. discovery order requiring discovery to take place in the U.S., because the discovery itself did not take place on French soil. According to the court:

What is required of [defendant] on French soil is certain acts preparatory to the giving of evidence. It must select

163. In English legal history the term "judicial sovereignty" was used to refer to the power of the King's Bench to supervise the inferior English courts by ordering writs of mandamus. III Blackstone's Commentaries on the Laws of England, 42 n.31 at 1056 (Lewis ed. 1922).

164. Report of the U.S. delegation to the 11th Session of the Hague Convention, 8 Int'l Leg. Mat. 785 (1969) [hereinafter cited as "the 1969 Delegation Report"].

165. 1969 Delegation Report, id. at 806.

166. See, e.g., Volkswagen Aktiengesellschaft v. Superior Court, 33 Cal. App. 3d 503, 109 Cal. Rptr. 219 (3rd Dist., 1973); Volkswagenwerk Aktiengesellscheft v. Superior Ct., 123 Cal. App. 3d 787, 176 Cal. Rptr. 874 (1st Dist., 1982); and Pierburg GmbH $\&$ Co. KG v. Superior Ct. of Los Angeles County, 137 Cal. App. 3d 238, 186 Cal. Rpt. 876 (2d Dist. 1982). 
appropriate employees to give depositions in the forum state: likewise it must select the relevant documents which it will reveal to its adversaries in the forum state. These acts do not call for French judicial participation. If [defendant] were preparing to bring litigation against United States adversaries in the United States courts, it would perform the same acts of selecting employee witnesses and evidentiary documents from its files without participation by a French judicial authority. In no way do those acts affront or intrude on French sovereignty. ${ }^{167}$

The court here uses the notion of judicial sovereignty to distinguish between those acts which violate French sovereignty-namely, those acts on French soil which constitute part of the state-regulated litigation process-and those which do not violate French sovereigntyi.e., those which are merely in preparation for the litigation process. ${ }^{168}$

In Germany, there has been little discussion of the relationship between sovereignty concepts and the validity of discovery, except in the context of the Hague Evidence Convention. 169 The assumption of writers as well as of the German government generally has been, however, that the concept of sovereignty is broader than it is assumed to be in the U.S. It is widely assumed that a discovery order by a U.S. court requiring conduct within Germany may violate German sovereignty, regardless of whether the conduct required is submission to discovery in Germany of the sending of documents or persons out of Germany for use in discovery in the U.S. ${ }^{170}$ Thus where an American court orders a German national to leave German territory to submit to depositions in the U.S. or to produce documents in the U.S., this may violate German sovereignty because it

167. Adidas (Canada) Ltd. v. S/S (Seatrain Bennington) 80 Civ. 1911, slip op. at 5 (S.D.N.Y. May 30, 1984).

168. Under the American Law Institute's tentative draft of the Restatement of the Foreign Relations Law of the United States, the concept of sovereignty is considered to prohibit the U.S. from issuing discovery orders which are insufficiently specified and inadequately supervised. This position has not been followed, however, in the United States cases. See A.L.I., Restatement of the Foreign Relations Law of the United States (Revised), Section 437 (Tentative Draft No. 6, 1985).

169. For discussion of the concept in the context of the Hague Evidence Convention, see e.g., Stuerner, supra n. 130 at 205-06.

170. According to the amicus brief of the Federal Republic of Germany in In re Anschuetz \& Co.:

Compliance in Germany with the order of the U.S. District Court mandating the taking of oral depositions in Kiel, Germany, and the production of documents located in Kiel, Germany, would be a violation of German sovereignty unless the order is transmitted and executed by the method of the Letter of Request under the Evidence Convention. (emphasis provided).

Brief of the Federal Republic of Germany, in In re Anschuetz \& Co., 754 F.2d 602 (5th Cir. 1985), at 8. 
involves coercion by the U.S. of conduct on German territory in violation of basic principles of the German legal system.171 In the German approach, therefore, the concept of sovereignty is closely associated with the private international law concept of ordre public.

The conflict between U.S. and German views of the scope of the concept of sovereignty would, therefore, appear to be explained, in part at least, by differences between the domestic law concepts which are use to interpret the principle of sovereignty. In the U.S. that principle has largely been defined in this context by reference to the concept of judicial sovereignty. If the concept of judicial sovereignty is used to define the scope of sovereignty, a court may simply avoid interference with a state's sovereignty by ordering the removal from that country of persons and documents sought to be examined. Where the principle of sovereignty is defined by reference to ordre public concepts a court may not order any conduct on foreign soil pursuant to proceedings which violate basic principles of the foreign legal system.

The role of the concept of sovereignty in the controversy over extraterritorial discovery is of central importance, but the current lack of adequate analysis of this issue allows each side to take positions based on assumptions which derive from its domestic legal system and correspond to its own interests. Consequently, Germany utilizes concepts that favor a broad notion of sovereignty protection, while U.S. courts favor more limited sovereignty protections.

\section{The Relevance of The Hague Evidence Convention}

Ironically, the conflict over extraterritorial discovery has been exacerbated by a multinational convention designed to ameliorate it. Uncertainty and confusion concerning extraterritorial discovery led in 1969 to a multilateral conference aimed at finding a solution to the problems created by differences in legal systems, in particular, by differences between civil law and common law countries. ${ }^{172}$ The result of this undertaking was the Hague Evidence Convention, opened for signature in 1970.

Prior to the Convention, international judicial assistance was generally not legally required. ${ }^{173}$ Except where governed by bilateral arrangements, each state could in its own discretion determine whether its courts would render such assistance. A primary objec-

171. See id. at 5.

172. See Edwards, "Taking of Evidence Abroad in Civil or Commercial Matters," 18 Int'l \& Comp. L.Q. 646 (1969).

173. For a discussion of the voluntary letters rogatory procedure, see 1 Ristau, International Judicial Assistance 106-16 (1985). 
tive of the Convention was, therefore, to make such assistance mandatory under certain circumstances.

Accordingly, each contracting state agreed that on proper request from a court in another contracting state its courts would take evidence within its territory for use in the foreign litigation. Although useful in many respects, the Convention left unclear certain issues which have become important aspects of the extraterritorial discovery conflict. The two main issues have been the treaty's scope and its relationship to domestic evidence-gathering procedures.

\section{The Exclusivity Issue}

The relationship between American discovery rules and the Hague Convention has been the main focus of the controversy. The issue is whether the Hague Evidence Convention is intended to be the exclusive or merely an additional means of obtaining evidence abroad.

Courts and commentators in the U.S. have taken divergent views. ${ }^{174}$ Three basic positions have been represented: (1) that the Convention is intended to be the exclusive means of obtaining extraterritorial evidence, the exclusive theory; (2) that the Convention is merely an additional device to accomplish foreign discovery and does not limit American courts in applying U.S. discovery rules, the optional theory; and (3) that in the interests of comity a good faith effort must be made to obtain evidence through the Convention, and only if Convention procedures are not successful, may domestic discovery rules be applied, the comity theory.

Although the U.S. Supreme Court has yet to take a position on the issue and there is little federal appellate case law, ${ }^{175}$ the courts have clearly rejected the mandatory approach. Courts and commentators generally have been divided between the optional theory and the comity theory. Followers of the optional theory have focused primarily on the fact that the Convention does not claim to be exclusive. Given the importance of the exclusivity issue, they say, it must be assumed that the treaty would state that it was intended to be exclusive, if, in fact, that had been the intention of the parties. ${ }^{176}$

174. For summaries of many of the cases in this area, see Hague Conference on Private International Law, Practical Handbook on the Operation of the Hague Convention of 18 March 1970 on the Taking of Evidence Abroad in Civil or Commercial Matters, pt. IV (1984) [hereinafter cited as "Hague Conference Handbook"].

175. This aspect of the Hague Evidence Convention is currently pending before the United States Supreme Court. See Societe Nationale Industrielle Aerospatiale, 106 S. Ct. 2888 (1986).

176. See, e.g., Lowenfeld, "Introduction: Discovering Discovery, International Style," 16 N.Y.U.J. Int'l L. \& Pol. 957, 959 (1984). 
Courts utilizing the comity theory agree that the U.S. is not obligated by the terms of the Hague Convention exclusively to utilize that Convention in securing foreign evidence. ${ }^{177}$ They take the position, however, that the doctrine of comity provides a middle ground between the optional and mandatory theories by imposing an obligation on U.S. courts to use the treaty wherever possible in order to avoid conflict with the interests of foreign states. Thus, they say, U.S. discovery rules will be applied only after the party seeking discovery has made a good faith effort to secure evidence through the procedures of the Convention.

The European countries, including Germany, generally take the position that the Hague Convention is intended to be exclusive. ${ }^{178}$ The states of Europe would have had no reason to sign the Convention, they argue, if it were simply another means for the United States to obtain discovery and involved no significant limitation on the rights of the United States. The U.S. would have achieved its objectives in the negotiations-namely, a means of securing the aid of foreign states in coercing the production of evidence, but surrendered very little. The Europeans, on the other hand, would have given up important sovereign rights and gained nothing. ${ }^{179}$

One explanation for the fact that the most fundamental issue related to the treaty - whether it was to be used exclusively or merely optionally - was left unclear relates to the differences between the respective systems and the values underlying them. Because of the conflict of procedural systems, the U.S. negotiators may not have realized how much the Europeans were surrendering in signing the agreement, and the Europeans may not fully have appreciated what the U.S. was attempting to achieve.

\section{U.S. Pre-Trial Discovery and The Scope of the Convention}

The second major area of controversy relates to the Convention's scope-specifically, the extent to which U.S. pre-trial discovery procedures are covered by it. Here again the problem may be traced to the apparent failure of each side to comprehend critical aspects of the other's legal system.

Courts and commentators in the U.S. generally have taken the position that the Convention was intended to apply generally to pretrial discovery and that the Convention would be virtually meaning-

177. See, e.g., Philadelphia Gear Corp. v. American Pfauter Corp., 100 F.R.D. 58 (E.D. Pa. 1983).

178. See, e.g., Brief of the Federal Republic of Germany as Amicus Curiae, in Volkswagenwerk v. Falzon, 461 U.S. 1303 (1983).

179. For discussion of the negotiations, see Amram, United States Ratification of the Hague Convention on the Taking of Evidence Abroad, 67 Am. J. Int'l L. 104 (1973). 
less from the American perspective if it were not to appy to pre-trial discovery, because that is the means by which facts are acquired for purposes of the U.S. litigation process. ${ }^{180}$ On that basis, it has been widely assumed that a U.S. attorney could merely send discovery requests appropriate under U.S. law to the foreign court via a U.S. court and expect that such foreign court would order production of the evidence requested.

Civil law countries argue, however, that the Convention was not intended to provide a mechanism for the enforcement of U.S. pretrial discovery rules as applied in the United States. ${ }^{181}$ In their view the Convention is a means of regulating international judicial cooperation among the contracting states. Since international judicial assistance is provided only for requests issued and considered by a judge which seek specified information, the treaty is not applicable to requests not meeting these requirements. Consequently, U.S. requests generally are considered not to qualify for international judicial assistance, because they are often not made and considered by a judge, and they often do not seek specific information.

The language of the Convention makes such conflict virtually inevitable. The Convention provides, in Article 1, that "a Contracting State may ... request the Competent Authority of another Contracting State, by means of a Letter of Request, to obtain evidence, or to perform some other judicial act." It then states that "A Letter shall not be used to obtain evidence which is not intended for use in judicial proceedings, commenced or contemplated."

From the perspective of the American legal system, the language of the second quoted sentence would appear generally to include pre-trial procedures, because, by negative implication, it includes evidence "for use in judicial proceedings, commenced or contemplated", and the function of U.S. discovery is to provide information for judicial proceedings-namely, the trial. From the German perspective, however, the critical point is that the quoted language specifically excludes "evidence which is not intended for use in judicial proceedings." Thus, the language would appear to exclude evidence which has not been adjudged to meet generally applicable relevance standards for use in judicial proceedings. Since U.S. pre-trial discovery standards of relevancy are not only lower than generally applicable relevancy standards in other countries, but also

180. See, e.g., Report of the United States Delegation to the Special Commission on the Operation of the Convention of 18 March 1970 on the Taking of Evidence Abroad in Civil or Commercial Matters 12-15 June, 1978, 17 Int'l Leg. Mat. 1417, 1421 (1978).

181. For the position of the German government, see Deutsche Denkschrift zu den Üebereinkommen, BT Drucksache VII Nr. 4892, reprinted in Schuetze, supra n. 166 at 715. See also Martens, supra n. 52 at 729, and Schlosser, supra n. 102 at 381. 
lower than admissibility standards in U.S. courts, and since a judge need not rule on their applicability at the discovery stage, discovery according to U.S. rules would be precluded.

The ambiguity is compounded by Article 23 of the Convention, which was proposed by the United Kingdom late in the negotiations. This article permits a contracting state to "declare that it will not execute Letters of Request issued for the purpose of obtaining pretrial discovery of documents as known in Common Law Countries", and virtually all contracting states have made reservations in accordance with it. ${ }^{182}$

The U.S. argues that the inclusion of this provision supports the negative inference that pre-trial discovery was intended generally to be covered by the Convention, since otherwise there would have been no need to include it. European countries argue, however, that this provision was merely added to secure the support of many countries which wanted specific language concerning the most objectionable aspect of U.S. discovery, namely, document production. ${ }^{183}$

Again, the controversy appears to result from a failure of each side to understand the perspective and, therefore, the legal argument of the other. From the European perspective, the Convention was drafted in such a way as to be applicable to U.S. discovery, provided that such discovery met generally applicable standards of relevancy and judicial supervision. Therefore, Article 23 merely allowed states the option of totally excluding a specific form of discoverynamely, discovery of documents. From this perspective, the inclusion of Article 23 does not permit a negative inference to be drawn with regard to the Convention's applicability to pre-trial discovery in general. Consequently, the American argument is based on a misapprehension of the position of the European negotiators. ${ }^{184}$

Similar problems of comprehension affect the role assigned by each side to Article 12 of the Convention, which provides, in relevant part, that a contracting party may refuse to execute an otherwise valid letter of request where "the State addressed considers that its sovereignty or security would be prejudiced thereby." In Germany, as in other European countries, this provision is interpreted to refer to ordre public principles. ${ }^{185}$ Under this view, Article 12 authorizes a German court to refuse to honor a request for

182. For information concerning the declarations of each contracting state, see Hague Conference Handbook, supra n. 174 at pt. III.

183. It is generally agreed that this article was poorly drafted. See 1978 Commission Report, supra n. 180 at 1428.

184. See generally, Schlosser, supra n. 102 at 381 .

185. See generally, von Huelsen, "Kanadische und Europäeische Reaktionen auf die U.S. 'pre-trial discovery,'" 28 Recht der Internationalen Wirtschaft 550 (1982). 
judicial assistance which violates such principles. ${ }^{186}$ Since, therefore, U.S. pre-trial discovery may, under some circumstances, violate Germany's ordre public principles, Article 12 provides an additional means of restricting the Convention's scope in relation to pre-trial discovery.

In the U.S., on the other hand, there has been virtually no mention of Article 12 in the case law and literature relating to the Hague Evidence Convention. A likely explanation is that American law has no ordre public concept and pays little attention to generally analogous concepts in its own system. Moreover, the American system does not relate such domestic law concepts to the international law principle of sovereignty. As a result, the U.S. has failed to appreciate a concept fundamental to the European understanding of the Convention.

The controversy surrounding the Hague Evidence Convention is thus derived, in large part, from failures on each side to understand, or accord significance to, the conceptual and institutional perspectives of the other side. This means, however, that recognition of the systemic differences which have led to the controversy should also provide a basis for improving the Convention.

\section{Concluding Perspectives}

The international conflict involving American extraterritorial discovery practices results from two facts. First, the procedural system in the United States acquires information through means which tend to be more intrusive and less carefully supervised than their foreign counterparts. And, second, the U.S. seeks to utilize its domestic information-gathering techniques with regard to information located outside the U.S. and in so doing often violates fundamental concepts of justice in the country in which the information is sought to be compelled. It is the combination of systemic differences with the attempt by one state - i.e., the United States - to utilize its system outside of its own territory which creates the conflict.

Resolving this conflict is made more difficult by the fact that the very systemic differences which underlie the conflict also impede each side's understanding of the other side's position. In this context, therefore, comparative analysis can perform two interrelated functions. First, it can explain the systemic differences that underlie the conflict and thus provide the basis for effective analysis, communication and cooperation. In addition, it can identify the interests of each side in the conflict and thereby indicate means of avoiding or reducing conflict in particular areas. In the extraterrito- 
rial discovery conflict, as so often in international conflicts, major concepts acquire symbolic importance and tend to obscure recognition of the actual interests involved.

\section{Nature and Function of Pre-Trial Discovery}

A critical element of the extraterritorial discovery conflict has been misunderstanding of the nature and function of American pretrial discovery. ${ }^{187}$ In the extraterritorial discovery controversy the issue is often posed in all-or-nothing terms. American lawyers often resist any limitations on discovery; Europeans often say it may not be used extraterritorially. Closer analysis suggests, however, that only certain characteristics of pre-trial discovery create conflict.

Pre-trial discovery has become an integral and necessary part of the American litigation process. Consequently, no international arrangement which completely eliminates the opportunity to gather information prior to trial can be accepted by the United States.

Pre-trial discovery need not, however, violate fundamental principles of German law. The fact that evidence is gathered prior to trial does not appear to violate basic concepts of justice in the German system. What is critical from a German perspective is the lack of principled judicial supervision of U.S. discovery procedures and their consequent potential for abuse.

Thus, by requiring increased supervision of the discovery process by its courts, the U.S. can eliminate an important element of the conflict. Moreover, this can be done without requiring the sacrifice of fundamental interests. From the American perspective, the central concerns are to maximize opportunities to acquire evidence for use in U.S. litigation as well as to assure that U.S. judgments are recognized and enforced.

\section{Scope of Pre-Trial Discovery}

A second major aspect of the conflict relates to the scope of the U.S. discovery process. The problem here is that U.S. discovery rules subject a significantly broader range of information to the litigation process than does German law, with the result that U.S. discovery procedures may significantly impinge on spheres of privacy protected by German law. Conflict may be reduced, therefore, to the extent that the U.S. can, without sacrificing its own fundamental interests, limit the scope of discovery where it conflicts with fundamental German interests.

For example, by raising the standard of relevancy for extraterritorial discovery, the U.S. could substantially reduce conflict with 
German interests. If the U.S. were to require that a party seeking extraterritorial discovery provide reasonable grounds to believe that the information sought would directly relate to proof of a material fact, the use of such a standard of relevancy would appear to satisfy the essential concerns of the German legal system, for it would minimize opportunities for parties to use discovery to "probe" for usable information. The resulting relevancy standard would not be as high as the German standard, but it would appear to be sufficiently high to protect Germany's basic interests. ${ }^{188}$ Moreover, such a move would not appear to violate fundamental interests of the U.S. It would exclude only that discovery which is least likely to produce usable evidence-namely, discovery as to which the requesting party has no reasonable grounds to believe would yield material information.

Confidentiality issues also provide opportunities for conflict reduction. For example, the German system recognizes the lack of direct interest of a non-party in litigation by providing significantly greater protection from the intrusions of the litigation process for non-parties than for parties. ${ }^{189}$ In the U.S. there is often relatively little difference in the scope of obligations between parties and nonparties, and the protection of both is generally less than in Germany.

The United States could, therefore, reduce conflict by broadening the confidentiality protection accorded to non-parties. It could, for example, provide that discovery would be permitted against foreign non-parties only where some relationship (such as a business or familial relationship) exists between the party seeking discovery and the foreign non-party. This would reduce the opportunity for plaintiffs in U.S. courts to use discovery to probe for foreign business information.

Germany, on the other hand, could reduce conflict by reducing or eliminating protection from U.S. discovery where the person seeking such protection is a plaintiff in the litigation in which discovery is sought. The possibility that a foreign plaintiff may carry out discovery of his domestic opponent without himself being subjected to discovery affects fundamental fairness interests of the U.S. and has been a cause of great concern in the U.S. Germany could, therefore, consider the use of U.S. courts to constitute a waiver of some or all of those rights which a person may otherwise have for protection against U.S. discovery orders in the same litigation. Germany would not have to allow discovery on its territory. It could

188. The German justice department has drafted regulations which essentially allow pre-trial discovery of documents, provided there is no such "probing". Unpublished draft regulation of German Federal Ministry of Justice, dated 15 June 1983. For a brief description of the contents, see Martens, supra n. 52 at 128.

189. See supra, text accompanying n. 111-116. 
merely decline to view orders for the removal of documents or persons from Germany as violations of its sovereignty. Such a step would not appear to impair fundamental German interests, because persons affected would have voluntarily relinquished sovereignty protections.

Reducing conflicts along the lines indicated by these examples can be accomplished in one or both of two ways. Such conflict reduction could be achieved by revising the Hague Evidence Convention. Almost a decade of experience and analysis has revealed systemic conflicts and operating difficulties which were not apparent when the Convention was drafted in 1968. Utilizing this experience and knowledge, a multinational conference to amend the Hague Convention may now be in a position to achieve substantial improvements in that Convention.

Provided that this experience can be brought to bear on the relevant negotiations, such a conference is likely to be the most effective means of resolving existing conflicts, not least because it would eliminate the conflicts which flow directly from the existing Convention and because it would provide a context for resolving a variety of conflicts at the same time. Moreover, it may be politically more acceptable for one state to make modifications of its own rules where this is part of a quid pro quo for changes from other states.

Alternatively, the U.S. might "adapt" certain of its discovery principles for use in the international context. The U.S. has chosen to adopt practices that other states do not allow and to apply them to conduct within the territory of other states. It is, therefore, in a position unilaterally to reduce the conflicts that result from its action, provided, however, that in so doing it does not thereby sacrifice its own fundamental interests.

The primary goal of the U.S. should be to move toward a system of international legal relationships which serves the essential objectives and values of the American litigation system. In this context those would appear to be maximum access to relevant facts, relative efficiency in U.S. litigation, and maximum foreign recognition of U.S. judgments.

Each of these goals can be achieved only with the support of the foreign countries involved. In addition to measures such as blocking statutes which have already been taken, there are many steps which a foreign government can take to thwart U.S. discovery within its territory. Foreign courts can, for example, refuse to recognize U.S. judgments based on excessive discovery, and foreign legislatures can provide legal remedies within their own jurisdictions against American citizens or corporations who utilize such discovery ${ }^{190}$ 
Consequently, failure to move toward resolution of the existing conflicts can be expected to lead to extreme uncertainty surrounding internation litigation in U.S. courts and impairment of the system of private law relationships between the U.S. and other foreign countries. Such a development would benefit no one, least of all American litigants. 